Az MTA rendes tagjának székfoglalója, 2017.

\title{
AZ ETNIKAI ALAPÚ TERÜLETI AUTONÓMIÁK MÚLTJA ÉS JELENE A KÁRPÁT-MEDENCÉBEN
}

\author{
Kocsis Károly
}

\section{Bevezetés}

A 19. századi nemzetállamok építőinek ideálja, az „egy állam - egy nemzet” elve az elmúlt évszázadban lezajlott etnikai tisztogatások, kényszermigrációk, az eröltetett asszimiláció ellenére, valamint a bátorított illetve eltürt bevándorlók (pl. vendégmunkások, menekültek) tömeges megjelenése miatt szinte egyik európai államban sem valósult meg. Kontinensük jelenlegi 700 milliónyi lakosa közül csupán $81 \%$ az egyes országok államalkotó nemzeteinek tagja, $10 \%$ az öshonos (autochton) nemzeti- és etnikai kisebbségeket alkotja, míg a maradék 9\% ún. ,jövevény” (allochton, az elmúlt évszázadban bevándorolt) etnikai közösség tagja. A fentiekben említett nemzetállami homogenitáshoz a népszámlálási adatok szerint az európai országok közül (a kisállamokat leszámítva) legközelebb Albánia, Lengyelország, Portugália áll, ahol a lakosságnak több mint $95 \%$-a az államalkotó nemzet tagjának számít. Etnikainyelvi szempontból leginkább tarkának (a sajátos etnikai-politikai helyzetű Belgiumot, Boszniát, Ciprust és Svájcot, illetve az egy milliónál kisebb népességü államokat figyelmen kívül hagyva) Lettország, Macedónia, Moldova és Észtország számít, hiszen esetükben a kisebbségek együttes aránya meghaladja a 30\%-ot.

Ez a jelentős, egyes esetekben fokozódó etnikai-nyelvi tarkaság, a 2. világháború emlékeinek tompulása, majd a volt szocialista szövetségi államok széthullása következtében az 1960-as évektől kezdve az államokon belüli etnikai konfliktusok száma és intenzitása megnőtt. Az esetek többségében megfigyelhető volt, hogy a konfliktusok hátterében a kisebbségek kollektív (autonómiát is magában foglaló) jogainak merev elutasitása és ennek eredményeként a kisebbségek elszakadási törekvései álltak. A hajdani Jugoszlávia és Szovjetunió területén az 1990-es években lezajlott belső háborúkat követően az ilyen jellegü konfliktusok többségét már békés úton, tárgyalásokkal próbálták rendezni, sőt egyes, korábban erősen központosított nyugati nemzetállamok esetében megfigyelhető volt a decentralizáció, a regionális önkormányzatiság felé való elmozdulás is (Benedikter, T. 2009). A szilárd demokratikus hagyományokkal rendelkező, területi, kulturális heterogenitását (f)elismerő, a Balkán és a volt Szovjetunió egyes területein fellángoló konfliktusokat elkerülni kívánó államok közül, hosszú előzmények után elsősorban Olaszország, Spanyolország, Belgium és az Egyesült Királyság törekedett a területi hatalommegosztás különböző formáit elmélyíteni, melyek közül a szövetségi és társult államisági rendszer mellett az autonómia a leggyakoribb. Az autonómia lehet nem-etnikai (regionális) és lehet etnikai jellegü. Az előbbire példa lehet Spanyolország és Olaszország néhány, nem kisebbség lakta autonóm régiójának (pl. Andalúzia, Madrid, Szicília) státusa. Az utóbbi, etnikai jellegü autonómia (az etnikai-földrajzi feltételek megléte esetén) lehet területi (pl. Dél-Tirol, Åland-szigetek, Katalónia, Tatárföld) vagy lokális, illetve személyi (kulturális) jellegü (Benedikter, T. 2009).

„A területi autonómia egy földrajzilag meghatározott térség, mely az adott ország egyéb területi egységeitől eltér és különleges, törvényhozó illetve szabályozó (közigazgatási) halatommal felruházott státussal rendelkezik" (Ackrén, M. 2009, p.20). A múltban az autonómia ilyen formáját az elszakadás felé tett első lépésnek, a létező államok felbomlasztása eszközének tekintették (Pan, C. - Pfeil, B.S. 2003). Ma már a pozitív nemzetközi tapasztalatok alapján úgy véljük, hogy a területi autonómia a kisebbségvédelem 
legfejlettebb eszköze és a kisebbségek belsö önrendelkezésének legmodernebb formája, mely az adott állam (annak államalkotó nemzete) és a nemzeti kisebbségek közötti kompromisszumnak tekinthető, mely biztosítja a kisebbségek számára az alapvető emberi jogok közé tartozó autonómiát, az államnak pedig területi integritásának megőrzését, határainak sérthetetlenségét.

Az állam területi egységének megőrzése és a kisebbségi kollektív jogok (önkéntes vagy kényszerü) megadása érdekében Európában eddig föként a skandináv, olasz, spanyol, brit területeken és Oroszországban került sor területi autonómiák megvalósítására (1. ábra). Feltünő ugyanakkor, hogy az erösen központosított nemzetállamok példaképe, Franciaország és a volt szocialista kelet-közép- és délkelet-európai országok területén - a kisebbségek vélt szecessziós törekvéseitől való rettegés miatt - erre még nem kerülhetett sor. A nemzetközi tapasztalatok alapján etnikai alapú területi autonómia (a politikai feltételektől ezúttal eltekintve, szigorúan csupán etnikai-földrajzi szempontból) csak ott müködhet sikeresen, ahol az adott kisebbség etnikai tere (többé-kevésbé) összefüggő illetve ezen a területen abszolút (demográfiai) többséget képvisel (tehát szülőföldjén az államalkotó nemzet tagjai demográfiai kisebbségben élnek). Ilyen szempontból Franciaországban Elzásznak (németek), AlsóBretagne-nak (bretonok), Észak-Baszkföldnek, Észak-Katalóniának és Korzikának kellene az önrendelkezés ilyen formájával rendelkeznie. Ugyanez mondható el a volt szocialista országokban élö némely kisebbségekre is (pl. lengyelek Litvánia és Belarusz határvidékén, törökök Bulgáriában, bolgárok Szerbiában és Ukrajnában, szerbek Észak-Koszovóban, bosnyákok a szerbiai Szandzsákban, illetve magyarok a Kárpát-medencében).

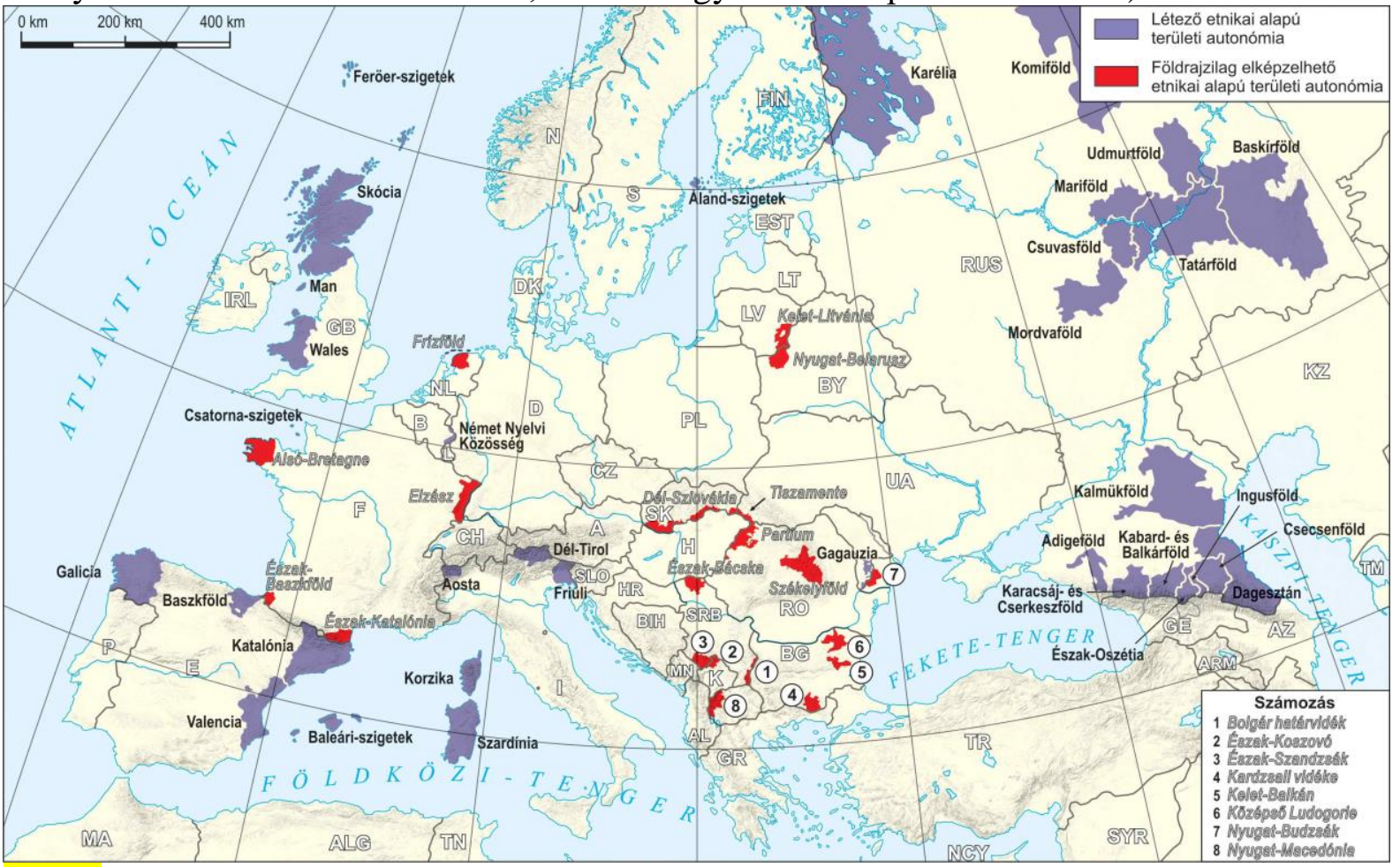

1.ábra Létezö és földrajzilag elképzelhetö, etnikai alapú területi autonómiák Európában

\section{A Kárpát-medencei területi autonómiák történeti gyökerei}

Hazánk, a 28 millió lakosnak otthont adó Kárpát-medence államjogi-etnikai helyzete hasonló az európai átlaghoz, hiszen lakóinak $84 \%$-a élvezi az államalkotói státust. A többi, alapvetően nemzeti-etnikai kisebbségnek számító lakos közül a két világháború után rögzített államhatárok és népmozgalmi okok következtében csupán a magyar kisebbség (pontosabban 
nekik is mindössze 2/3-a) rendelkezik olyan településterülettel, mely megfelel a területi autonómia elöfeltételeinek. A többi kisebbség alapvetően nyelvszigeteken és szórványokban küzd fennmaradásáért, ahol legfeljebb lokális vagy kulturális autonómia megvalósítására van lehetőség.

\section{Az 1918 elötti idöszak}

Kevéssé ismert tény, hogy a Kárpát-medencét az európai területi autonómiák bölcsőjének is nevezhetjük, ahol egyes régiók és etnikumok a középkortól a 19. század derekáig széles körü autonómiával rendelkeztek.

A Kárpát-medencén belül leghosszabb (közel 800 éves) regionális területi önkormányzattal - I. (Szent) László és Kálmán királyaink 1091-1097 közötti hadjáratai eredményeként a Magyar Királyság részévé vált - Horvátország rendelkezett, mely a Tengerfehérváron (Biograd na Moru) Kálmán király és a horvát arisztokrácia között 1102-ben megkötött egyezmény (Pacta conventa) értelmében, perszonálunió formájában a magyarhorvát államközösség idején megőrizte területi különállását, önkormányzatiságát, melyet a horvát-dalmát és szlavón bán, illetve rendi gyülésük, a szábor (sabor) is jelképezett. A Dráva és a Dinaridák részét képező Nagy- és Kis-Kapela-hg. között elterülő Szlavónia (Tótország, Szlavónország) a 11. század elejétöl, illetve a Zágrábi-püspökség Szent László által történt megalapításától, 1091 után lett tartósan a Magyar Királyság része, melyet dukátusként (hercegségként) a 12. századtól a trónörökösök, a királyi család egyéb tagjai, vagy a szlavón bánok irányítottak (2.ábra). Horvátország és Szlavónia különböző mértékủ autonómiája 1526 után, a Habsburg fennhatóság idején jelentős mértékben csökkent, kiterjedése a török hódítás következtében $\mathrm{kb}$. harmadára zsugorodott. Ennek és a hatalmas méretü migrációknak köszönhetően a horvát államiság súlypontja (és Horvátország fogalma) a tengermellékről az északi, szlavón területekre, Zágráb környékére került, míg Szlavónia fogalma kelet felé, az 1684-1688 között az Oszmán Birodalomtól visszafoglalt, Dráva-Száva közötti területekre tolódott (Szabó P. Z. 1945). 1790 után Szlavóniát már Horvátországgal együtt, annak részeként említik. 1848-ban, a magyar forradalom és szabadságharc idején Magyarországgal a közjogi kapcsolatok megszakadtak, melyek csupán 1868-ban, a horvát-magyar kiegyezéssel álltak helyre, mely ismét a Magyar Szent Korona részeként ismerte el a Horvát-Szlavónország nevü, rendkívül széles területi autonómiával ellátott királyságot. Ezt az államközösséget, a magyar államon belüli területi autonómiát a horvát szábor az Osztrák-Magyar Monarchia összeomlása után, 1918. október 29-én mondta fel és csatlakozott később az újonnan létrejött délszláv államalakulathoz (Szerb-Horvát-Szlovén Királysághoz, Jugoszláviához), melynek keretein belül csak jóval később (1939-1941, 1974-1991) élvezhette ismét azt a belső önállóságot, melyre 1918 előtt a horvát-magyar államközösségben volt módja. A szlavón és horvát területeknek a Magyar Királyságon belüli önállósága formailag ugyan a mai fogalmak szerint inkább regionális területi autonómiának volt felfogható, de arra való tekintettel, hogy népességük többsége délszláv (a 16. század derekáig szinte teljes egésze katolikus délszláv: szlavón/tót, horvát) volt, ezen területek belső önállósága akár etnikai alapú területi autonómiaként is értelmezhető. 


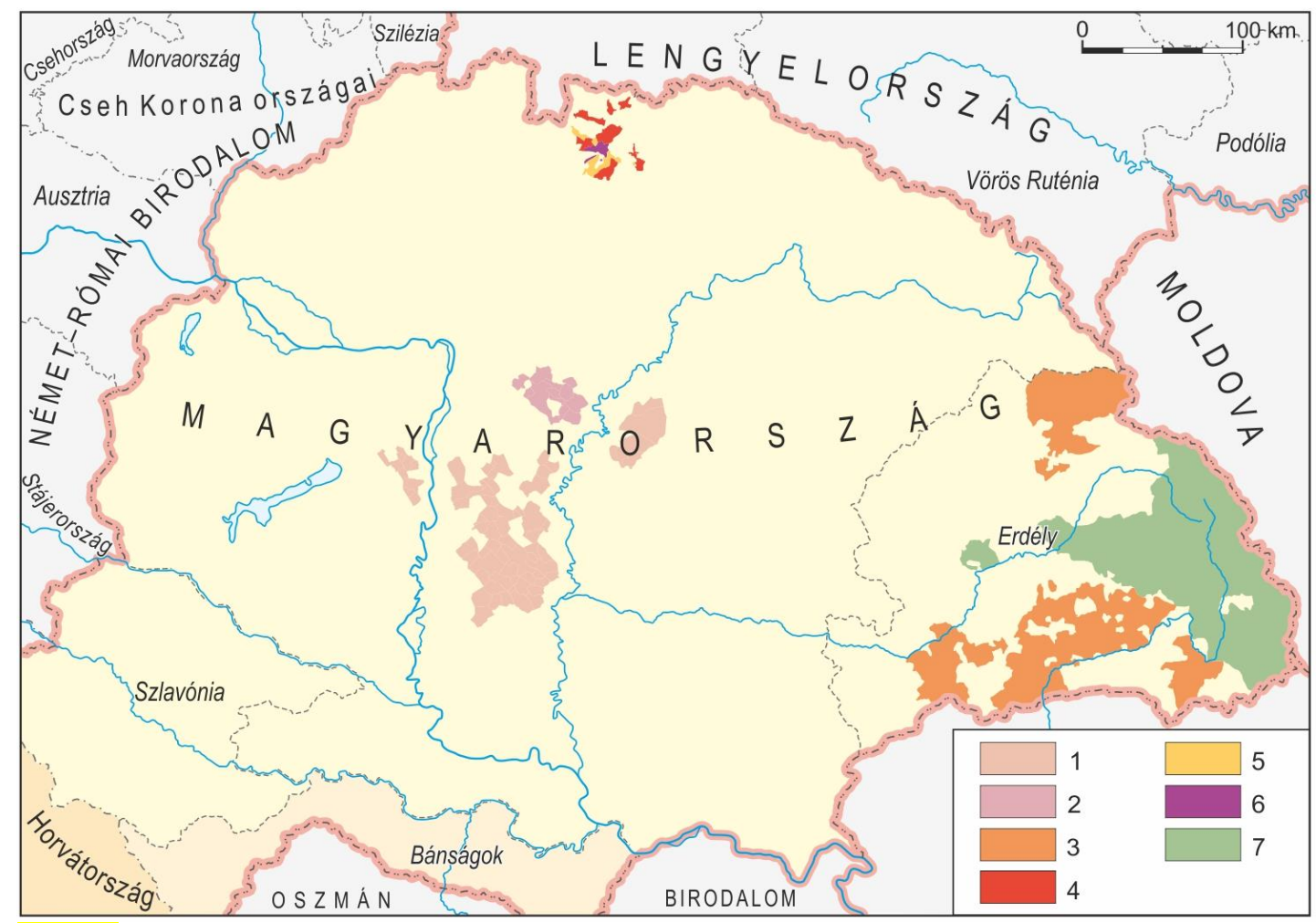

2.ábra Területi autonómiák a Magyar Királyságban a 15. század végén

1 = Kun székek; 2 = Jászság (Jazygia); 3 = Szász székek Erdélyben; $4=16$ szász szepesi város ${ }^{1}$ (lengyel zálogban); $5=11$ szász szepesi város; 6 = Szepesi “Tízlándzsás szék (Sedes X lanceatorum)”; 7 = Székely székek

A magyar államiság első évezrede alatt a regionális területi autonómia különböző fokozatait gyakran testesítette meg a Kárpátok láncai által körülzárt Erdély (Erdélyország, Erdőelve) is, elsősorban az állami magterülettől (Esztergom, Buda, Visegrád, Székesfehérvár) való nagy távolsága és sajátos földrajzi helyzete miatt. A magyar királynak a 11. századtól mercurius princepsnek, majd vajdának nevezett képviselöje a középkor folyamán olyan mértékben biztosított a tartománynak regionális területi autonómiát, amilyen mértékben változott a központi hatalom ereje. Mohács (1526) után az Erdélyi vajdaság, a kettős királyválasztás eredményeként a Szapolyai János (korábban vajda, immár I. János király) uralta keleti Magyar Királyság törzsterületévé vált. Később, a speyeri szerződés (1570) értelmében (elvileg a Magyar Királyság elidegeníthetetlen részeként) már „csak” fejedelemségként biztosította a következő évszázadban a független magyar államiság eszméjének továbbélését. Az 1541-től oszmán vazallusnak számító magyar államalakulat az Oszmán Birodalmon belül rendkívül széles regionális területi autonómiával, többnyire alig korlátozott szuverenitással rendelkezett. Ez a viszonylagos önállósága szünt meg a török kiüzését követően. Az I. Lipót császár által 1691-ben kiadott Diploma Leopoldinum következtében Erdély a magyar korona országaként és magyar közjogi státussal ugyan, de önálló államisággal (fejedelemségként, 1765-től nagyfejedelemségként) vált a Habsburg Birodalom részévé, örökös tartományává. Erdély és Magyarország törvényi újraegyesítésére ezt követően először az 1848. évi VII.tc., majd az osztrák-magyar kiegyezést követő, 1868. évi XLIII.tc. értelmében került sor, mely utóbbi eredményeként - az egységes magyar nemzetállam célkitüzéseinek megfelelöen - véglegesen felszámolták Erdélynek még a középkori magyar államon belül is élvezett viszonylagos területi önállóságát.

A középkorban uralkodóink számos, birtokaikon letelepített etnikai közösségnek, társadalmi csoportnak adtak katonai szolgálataik fejében kollektív, a közösség egészére és egy

\footnotetext{
${ }^{1}$ Az ún. „XIII szepesi város” fogalmába nem tartozó Gnézda, Podolin és Ólublóval együtt.
} 
adott területre érvényes, olykor több évszázadon át élvezett, önkormányzati jogokat. Ezen kiváltságok többsége megfelelt a mai értelemben vett etnikai alapú területi autonómiáknak. Ilyen privilégiumokat tartalmazó, Európában is elsőnek számító okirat II. András királyunk 1224-ben kiadott oklevele (Andreanum) volt, mely az erdélyi szászoknak területi alapú kollektív jogokat biztosított (Érszegi G. 204). A szásznak nevezett, kezdetben a Rajna, Mosel és Luxemburg vidékéről, a 12. század második felétől betelepített német ajkú telepesek Szeben székhelyü autonóm területe Dél-Erdélyben, a Szászváros és Barót közötti területen jött létre. A reguláris, nehézfegyverzetü bizánci hadsereg támadásai által veszélyeztetett délerdélyi határ védelme érdekében betelepített „szász" népesség a 12-14. században fokozatosan költözött az onnét lépcsőzetesen, a Keleti-Kárpátok övezetébe áttelepített, könnyülovas székely határőr népesség helyére. A területi autonómiára jellemző jogokon kívül a szászok nagyobb települései vásártartási és árumegállítási jogot is kaptak, mely a 14. századtól rohamos urbanizációt eredményezett településterületeiken. Az erdélyi szász autonómia 1486-ban vált területileg teljessé, amikor Hunyadi Mátyás az Andreanumban foglalt kiváltságaikat, a szebeni szék joghatóságát az egész erdélyi szász etnikai területre (Királyföld, Beszterce- és Brassó-vidéke) kiterjesztette, létrehozva ezzel a „szász univerzitás” (Universitas Saxonum) nevü autonóm területi egységet (Müller, G. E. 1928, Hanzó L. 1941). A reformáció idejétől, környezetüktől (evangélikus) felekezetükben is elkülönülő szászok területi autonómiája ideiglenesen II. József és a Bach-korszak idején (1785-1791 ill. 18521860), véglegesen pedig az 1876. évi országos közigazgatási reform (XXXIII.tc.) során szünt meg.

Az erdélyi szászokhoz hasonló, több mint 600 évig fennálló területi autonómiát élvezett a Magas-Tátra lábánál, a Poprád és Hernád folyók völgyébe a 12. századtól telepített szepesi szászok többsége is. Kiváltságaikat V. István 1271-ben erősítette meg és foglalta településterületüket egy zárt, a vármegyétől független, Lőcse székhelyü, autonóm provinciába (universitas seu provincia Saxonum de Scepus) (Fekete Nagy A. 1934). Szokásjogukat I. (Nagy) Lajos 1370-ben megerösítette és törvénybe foglalta (Zipser Willkür). A 24 szepesi szász város közül 13-at Zsigmond király 1412-ben elzálogosított Lengyelországnak, ahol autonómiájuk az 1770 (1772)-es visszacsatolásukig is fennmaradt (Žudel, J. 1984). Míg az el nem zálogosított 11 szász város fokozatosan vármegyei igazgatás alá került, az 1770-ben visszatértek - 1778-ban kiegészülve Ólublóval, Podolinnal és Gnézdával - XVI szepesi város néven területi autonómiájukat egészen 1876-ig meg tudták őrizni.

A Szepesség kapcsán meg kell említenünk, hazánk egyik legrégebbi területi autonómiáját a szepesi Tízlándzsás széket (Sedes X lanceatorum), melynek lakói kezdetben kabar eredetű Gömör-őrök, később elmagyarosodott határőrök voltak, akiknek ősi kiváltságait (nemesi mivolt, adómentesség, bíráskodási önállóság, saját ispán stb.) IV. Béla 1243-ban erősítette meg (Fekete Nagy A. 1934). A tatárjárás idején a magyar lándzsásnemesek területe szétzilálódott, a 16. századtól szlovák többségüvé vált, majd több mint hat évszázados autonómiájuk 1802-ben (X.tc.) szünt meg a Szepes vármegyébe történt beolvadásukkal. Arra való tekintettel, hogy ezen kiváltságos terület népességének etnikai összetétele folyamatosan változott, a lakók többsége fennállásának első századaiban ráadásul az államalkotó etnikumhoz tartozott (magyar volt), így ezt az autonómiát nem igazán tekinthetjük etnikai alapúnak.

A fentiekben említett erdélyi szászok betelepítése és az ottani határör székelyek migrációja, későbbi autonóm területeik, a majdani Székelyföld kialakulása a 12-13. században egymással szoros kölcsönhatásban alakult. A honfoglalás óta hazánkban katonai feladatokat ellátó székelység bihari csoportjait a 11. században telepítették át Erdély déli részére, melyet a beköltöző szászok miatt a 12-13. században fokozatosan kellett elhagynia, hogy a keleti határ védőjeként végleges hazára leljen a Keleti-Kárpátokban. Új lakóhelyükön a 14-15. században (a szászokhoz, kunokhoz, jászokhoz hasonlóan) autonóm bírósági, 
közigazgatási, katonai hatáskörü területi egységeket (törvényhatóságokat), ún. székeket hoztak létre (Szádeczky Kardoss L. 1927, Endes M. 1935), melyek közül legrégebbinek a Telegdiszék (későbbi Udvarhelyszék), legújabbnak a Sepsi-, Kézdi-, Orbai- és Aranyosszék számított. A székely katonatársadalom kiváltságos helyzete a 16. századig maradt érintetlen, melynek helyreállítására - súlyos konfliktusok után - a székelyek haderejére rászoruló erdélyi fejedelmek 1601 után számos kísérletet tettek (Egyed Á. 2006). A székely területi autonómiát (csakúgy mint minden más hasonló helyzetü közigazgatási egységet) közel fél évezredes fennállás után a modern, központosított magyar nemzetállamot megvalósítani kívánó, 1876. évi „megyereform” (XXXIII.tc.) szüntette meg és olvasztotta be az újonnan létrehozott Csík, Háromszék, Maros-Torda és Udvarhely vármegyébe.

A 13. század derekán az országba hívott kunok etnikai területi autonómiájának alapjait a IV. (Kun) László által kiadott 1279. évi ún. kun törvények (alkotmánylevél) képezték (Bánkiné Molnár E. 2005). A Duna-Tisza közén és a Tiszántúlon (Kiskunságban, Nagykunságban) letelepített kunok eredeti nemzetségi szervezete a 15. század folyamán alakult át területi szervezetté, szász mintára szék-rendszerré (Kristó Gy. 2003). A később betelepült jászok hasonló, katonai szolgálatokért kapott kiváltsága az 1323. és 1407. évi (I. Károly Róbert és I. Zsigmond által kiadott) okleveleikhez köthető (Gyárfás I. 1870). Zagyva melléki településterületük 1480 körül alakult önálló, autonóm közigazgatási egységgé, székké (Fodor F. 1942, Pálóczi Horváth A. 1989). Az akkorra már nyelvükben véglegesen elmagyarosodott kunok és jászok helyhatósági önkormányzatát a török tiszteletben tartotta (1541-1686), de autonómiájuk a Habsburg fennhatóság idején, különböző okok miatt többször szünetelt: 1702-1745 (eladás), 1787-1790 és 1850-1860 (közigazgatási átszervezés) (3.ábra). A jász és kun - közjogilag a 17. századtól egyre inkább összefonódó - székek által alkotott autonóm terület, a Jászberény székhelyü Jászkun Kerület 1876-ban szünt meg és olvadt be az újonnan kialakított Jász-Nagykun-Szolnok, illetve Pest-Pilis-Solt-Kiskun vármegyébe. Az országba a 12-13. században szétszórtan telepített besenyők csupán Fejér és Tolna megyék határvidékén, a Sármelléken lévő ispánságuk területén, ott is csak rövid ideig (1321-1352) rendelkeztek területi autonómiával (Győrffy Gy. 1939).

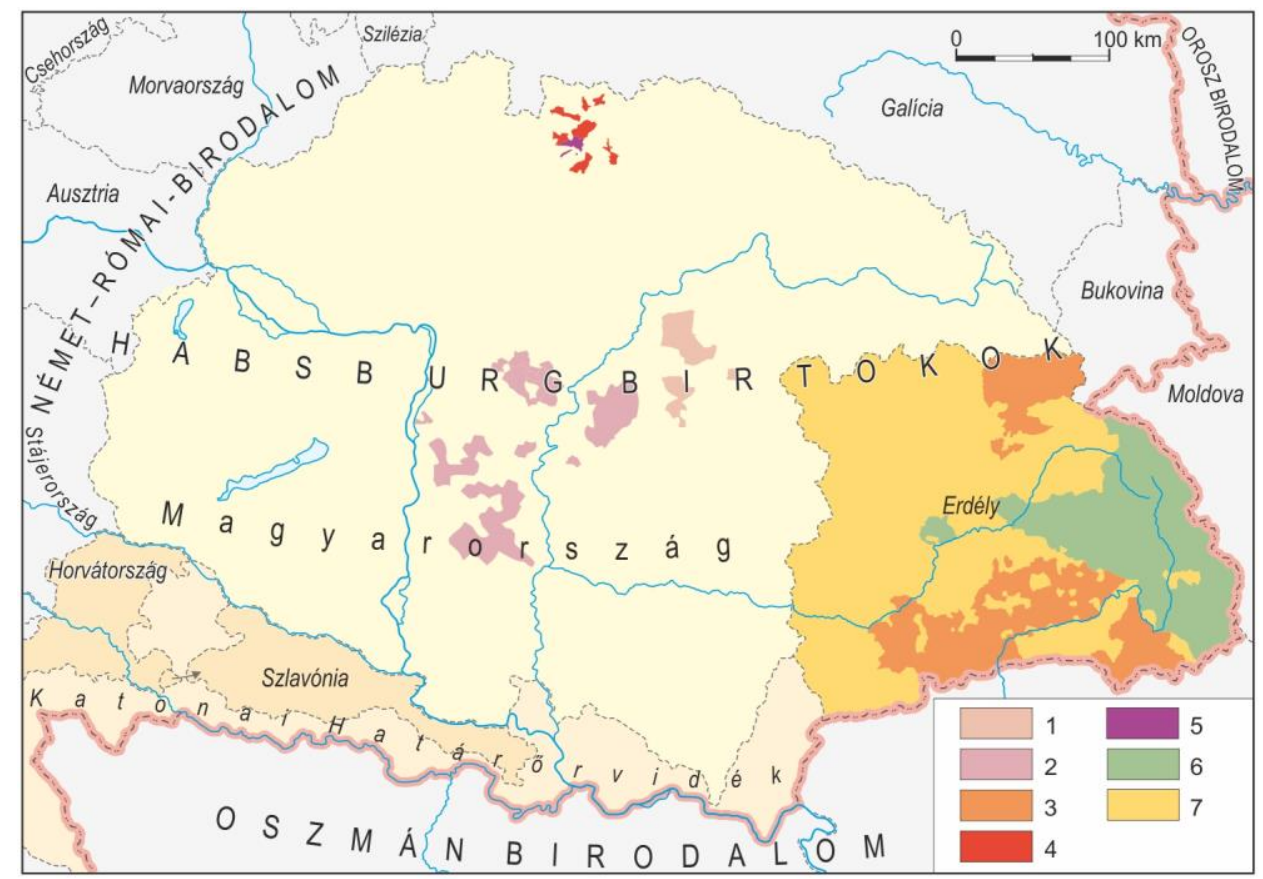

3.ábra Területi autonómiák a Magyar Korona országaiban (1780)

1 = Hajdú kerület; 2 = Jászkun kerület (Jazygia-Cumania); 3 = Szász székek Erdélyben; 4 = 16 szász szepesi város; 5 = Szepesi “Tízlándzsás szék (Sedes X lanceatorum)”; 6 = Székely székek; 7 = Erdélyi Nagyfejedelemség vármegyéi 
Az ország lakóinak túlnyomó többségétől (ortodox) felekezetében és (újlatin) nyelvében is elkülönülő románok (oláhok, vlachok, rumének) bevándorlása a tatárjárás után, főként a 14. századtól vált jelentőssé a Magyar Királyság területére (különösen a DéliKárpátokban, Máramarosban és az Erdélyi-középhegységben) (Fekete Nagy A. - Makkai L. 1941). A 14-15. században a Fogarasföldön, Máramarosban, Hátszeg-vidékén és a Szörénységben kenézek, krajnikok, bojárok, vajdák vezetésével már etnikai alapúnak is mondható, bizonyos fokú területi önkormányzattal is rendelkeztek. Ez a román autonómia azonban vezetőik nemessé válásával, elmagyarosodásával a későbbiekben elsorvadt és nem emelkedett arra a szintre mint a szászoké, vagy székelyeké (Fekete Nagy A. - Makkai L. 1941). Ugyanakkor meg kell említenünk, hogy a Szatmár és Belsö-Szolnok megyék közé ékelődő, katonai szolgálatot teljesítő, több mint 90\%-ban román népességü Kővár-vidék autonómiája, közigazgatási különállása a 14. századtól egészen 1876-ig megmaradt (Szentgyörgyi M. 1972).

Az elpusztult, magyarok által elhagyott délvidéki területeken a 16-17. században egyre inkább elterjedt, abszolút többségüket az 1830-as évekig megőrző szerbek ${ }^{2}$ a 18. század végétől, a modern nemzetek megszületésétől kezdve - ortodox egyházuk nyújtotta önkormányzatukon túl - egyre nyíltabban törekedtek a területi jellegü önrendelkezésre is. Az I. Lipót által 1690-95 között kibocsájtott privilégiumokon kívül, bizonyos fokú területi autonómiával (a magyar jogrendtöl való teljes függetlenséggel) már az 1700 és 1873 között fennállt, a Magyar Korona országaitól függetlenül, Bécsből irányított Katonai Határőrvidék (Militär-Grenze) szerb többségü területein (Péterváradi-, Német- és Illír-bánsági ezred, Sajkás/Csajkás kerület, 1700-1750 között a Tisza-Marosi határőrvidék) is rendelkeztek. A temesvári szerb nemzeti kongresszus 1790. november 4-én fölterjesztést intézett II. Lipóthoz a Dél-Magyarországon kialakítandó szerb területi autonómiáról, melyet a császár néhány hónappal később elutasított. Az 1848-49-es magyar forradalom és szabadságharc idején a szerbek területi autonómiára vonatkozó követeléseinek magyar kormányzati elutasítását követően a karlócai szerb nemzeti kongresszus 1848. május 13-15-én kikiáltotta az Osztrák Császárságon belüli autonóm Szerb Vajdaságot, melyhez Bács-Bodrog vármegye, a Bánság nyugati része, a Szerémség és Baranya délkeleti szeglete tartozott volna. A szabadságharc bukása után, 1849. november 18-án I. Ferenc József Bács, Torontál, Temes, Krassó és Szerém megyék polgári igazgatású részeiből létrehozta a Magyarországtól független „Szerb Vajdaság és Temesi Bánság" nevü tartományt, melyet 1860. december 27-én visszacsatolt az anyaországhoz. A rövid életü, nagy kiterjedésü (leginkább csak nevében szerb) provincia nem elégítette ki a szerbek igényeit, hiszen nemzetük a románok $(28 \%)$ és németek $(24,5 \%)$ után a közel 1,5 milliónyi népességnek mindössze 20,4\%-át jelentette (Hegediš, A. - Čobanović, K. 1991). A csalódott szerbek 1861. április 2-i karlócai nemzeti kongresszusukon ismételten követelték a Szerb Vajdaság, mint kizárólagosan szerb hivatalos nyelvü autonóm tartomány felállítását ${ }^{3}$, azonban annak kiterjedését már hozzávetőlegesen a szerb többségü területekhez igazították (Szerémség, Nyugat-Bánság és Bácska déli fele a Zombor-Kula-Mohol vonalig) (Đorđević, J. 1861) (4.ábra).

\footnotetext{
${ }^{2}$ A szerbek legnagyobb tömege I. Lipót felhívására 1690-ben érkezett Magyarországra (fóként a déli és a Duna környéki területekre), ahol fegyveres szolgálatuk fejében az uralkodó, mint autonómiával ellátott politikai nemzetet (natio rasciana) fogadta be őket (Czoernig, K. 1857, 157-158.).

3 „Azon terület, melyen a szerbek többségben vannak, Magyarországban, illetőleg a Horvát, Tót és Dalmát háromegy királyságban, ismertessék el szerb területnek „Szerb Vajdaság” nevezete alatt.” (Kemény G. G. 1952)
} 


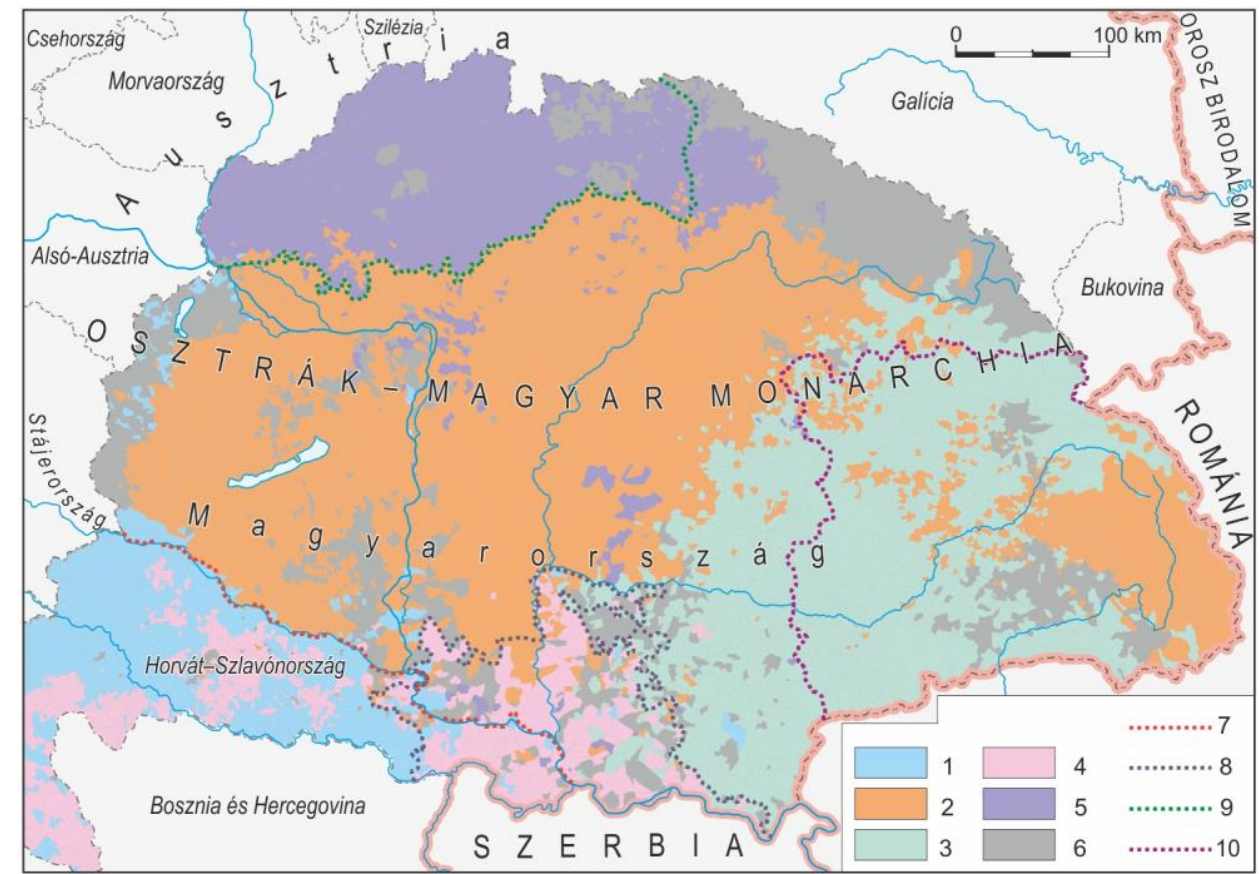

4.ábra Magyarország nagyobb nemzeti kisebbségeinek etnikai alapú területi autonómiára vonatkozó követelései (19. sz. másodikfelében)

1 = horvátok, bunyevácok, sokácok; 2 = magyarok; 3 = románok; $4=$ szerbek; $5=$ szlovákok; $6=$ egyéb etnikai csoportok; 7 = az autonóm Horvát-Szlavónország határa; 8 = a szerbek által követelt Vajdaság határa (1861. március 24.); $9=$ a szlovákok által követelt Felső-magyarországi Szláv Kerület határa (1861. június 7.); $10=$ a románok által 1867 után követelt autonóm Erdély határa

Ugyanezen évben, 1861. június 6-7-én a turócszentmártoni szlovák nemzeti kongresszus is etnikai alapú, Magyarország integritásán nyugvó, területi önkormányzatot kért Felső-Magyarország szlovák többségü területei (hornouhorské slovenské okolie) számára ${ }^{4}$ (Kemény G. G. 1952). Az igényelt szlovák autonóm terület a felvidéki szlovák többségü vármegyékre és a szomszédos vármegyék szlovák többségü részeire terjedt volna ki és határai a szlovák nyelvhatárhoz igazodtak volna.

A románok körében ez időszakban nem vált ismerté etnikai területükhöz igazított területi autonómia koncepció. Politikai emancipációs küzdelmeik keretén belül alapvetően a 17. század derekától már általuk többségében (1850-ben 59,5\%-ban) lakott Erdély autonómiájához ragaszkodtak csupán (Mester M. 1936).

Az országgyülés nemzetiségi képviselői 1867. február 11-én olyan törvényjavaslatot ${ }^{5}$ alkottak meg, mely hazánkban hat politikai nemzetet (magyar, román, szerb, szlovák, orosz /ruszin/, német) ismert el és - számos egyéb követelés mellett - igényt tartott volna a megyék, választókerületek határainak az etnikai viszonyokhoz való hozzáigazítására (,kikerekítésére”) (Kemény G. G. 1952). Ez utóbbi az ország peremterületein egymáshoz illeszkedő, nemzetiségi többségü autonóm területek halmazát hozta volna létre.

\footnotetext{
${ }^{4}$ „Szükséges, hogy nemzetünk individualitása azon területen, melyet az mint egy szakadatlan tömeg valósággal elfoglal, egy, a megyék határainak nemzetiség szerinti kikerekítésével alakítandó felső-magyarországi szláv kerületben (hornouhorské slovenské okolie) elösmerve s személyesítve legyen.” „Ugyanis egy nemzet nem eszményi lény, de tettleges valóság: nem elégséges tehát egy nemzetet szellemi átalánosságban elösmerni, de szükséges elösmerni azt úgy, amint valósággal van azon területi minőségben, melyben az tettleg létezik..." (Kemény G. G. 1952).

5 „Törvényjavaslat az országos nemzetiségeknek és nyelveknek Magyarországban leendő szabályozására és biztosítására. 1867. február 11." A 14 román, 12 szerb és egy ruszin képviselő által benyújtott (később Mocsonyi Sándor és Miletics Szvetozár nevéhez is kötött) törvényjavaslat a nemzetiségi törvény 1868. november 24-29. közötti vitája során mint „kisebbségi javaslat” került a parlament elé (Kemény G. G. 1952).
} 
Az osztrák-magyar kiegyezést (1867) követően, az 1868. évi XLIV. tc. (A nemzetiségi egyenjogúság tárgyában), a világ első nemzetiségi törvénye tulajdonképpen „kompromisszum volt az elvi liberalizmus, a nemzeti autonómiák rendszerét meghonosítani akaró nemzetiségi programok és az egységes magyar jellegü nemzetállamot követelők tábora között" (Szász Z. 1988). Az 1848-49-es magyar kormányhoz (alapvetően Kossuth Lajoshoz) hasonlóan, a francia államnemzeti eszmét követve a törvény Magyarországon csak egy és oszthatatlan magyar (politikai) nemzet létét ismerte el, függetlenül állampolgárai nemzetiségi, nyelvi kötődésétől (Katus L. 1993, 2002). Ennek megfelelően az OsztrákMagyar Monarchián belül területi autonómiával rendelkező magyar állam (a horvát-szlavón önkormányzatiságtól eltekintve) határozottan visszautasította kisebbségeinek etnikai alapú területi autonómia követeléseit, melyben elszakadásuk első lépcsőjét, az ország területi integritásának legfőbb veszélyforrását látta.

\section{Az 1918 és 1945 közötti időszak}

Az I. világháborút követően, az ország román, szerb és cseh megszállása, a katonai, politikai, gazdasági káosz idején a nemzetiségek különböző képviselői, csoportosulásai egymás után mondták ki a Magyarországtól való elszakadást. ${ }^{6}$ Az ,őszirózsás forradalom” (1918. október 25-31.) eredményeként hatalomra került Károlyi Mihály kormánya (főként a Jászi Oszkár tárcanélküli miniszter által létrehozott Nemzetiségi Minisztérium) történelmileg túl késonn, kétségbeesett kísérletet tett az ország területi integritásának megőrzése érdekében hazánk etnikai-területi alapú föderalizásálására (kantonizálására-helvetizálására), a nemzetiségekkel való kiegyezésre (Szarka L. 1990, 2008). Az 1918 novemberében folyamatosan előrenyomuló cseh, román és szerb csapatok által még meg nem szállt magyar területek román és szlovák nemzeti tanácsaival való megegyezés sikertelensége ${ }^{7}$ után a kisebb nemzetiségek megtartására helyezték a fö hangsúlyt. 1918. december 21-én törvénybe iktatták (X.tc.) a ruszinok területi autonómiáját (,Ruszka Krajna" nevü autonóm terület Ung, Bereg, Ugocsa és Máramaros vármegyék ruszin többségü területein). 1919. január 28-án (VI.tc.) a németek kaptak hasonló jogot területi autonómia létrehozására ${ }^{8}$ (Kemény G. G. 1952). A Károlyi-kormány harmadik nemzetiségi törvénye 1919. március 11-én (XXX. néptörvény Tótország-Slovenská Krajina önkormányzatáról) már teljesen anakronisztikus volt, hiszen a hivatkozott, cseh katonai megszállás alatt álló terület már de facto az antant által elismert Csehszlovákia részét képezte. ${ }^{9}$

A Tanácsköztársaság bukása után (1919.08.01.), az ország szinte teljes katonai megszállását követően a trianoni békediktátum 1920.06.04-én nemzetközi jogilag szentesítette a már 1918 végén bomlásnak indult, történelmi magyar államterület felosztását. Ennek eredményeként az ország közel 283 ezer $\mathrm{km}^{2}$-nyi területének 67,1\%-át, magyar anyanyelvü népességének 33\%-át csatolták a szomszéd államokhoz (Lőkkös J. 2000). Ezzel a

\footnotetext{
${ }^{6}$ A nemzetiségek vezetőinek elszakadási deklarációi: horvátok 1918. október 29. Zágráb, szlovákok 1918. október 30. Turócszentmárton, szerbek és bunyevácok 1918. november 25. Újvidék, románok 1918. december 1. Gyulafehérvár, erdélyi szászok 1919. január 8. Medgyes, ruszinok 1919. január 21. Huszt, május 8. Ungvár.

7 A románokkal való 1918. november 12-14-i aradi tárgyalások során Jászi Oszkár Erdély autonómiáját, autonóm erdélyi kantonok (4 román, egy székely, egy szász kanton és Kolozsvár multietnikus városi kanton) létrehozását javasolta. A szlovákoknak 1918. december elején, Budapesten egy széles körü autonómiával rendelkező „Tót Impériumot” ajánlottak fel, melynek déli határát az 1918. december 6-i Bartha-Hodža vonal jelölte ki (Szarka L. 1990).

${ }^{8}$ „2. § A németlakta vidékeken, amennyiben összefüggő területek, az ottlakó másajkú nemzetekkel egyetértőleg, autonóm jogterületek (kormányzóságok) alakíttatnak.” (Kemény G. G. 1952).

${ }^{9}$ Hasonlóképp irreálisnak tünt az adott pillanatban a Huszár-kormány által 1920. január 9-én elfogadott ,tót autonómia" terv is (Szlovenszkó területi autonómiájáról), mely ilyen módon próbálta a párizsi békekonferencián a döntéshozókat jobb belátásra bírni és a cseh politikusok korábbi, igen korán hamisnak bizonyult autonómia ígéreteiben csalódott szlovákságot a magyar állam keretei között megtartani (Tilkovszky L. 2000).
} 
magyar állam területén élő népesség etnikai homogenitása, a magyarok aránya rendkívül megnőtt (1910-ben 54,6\%-ról 1920-ban 89,6\%-ra), a kiterjedt nemzetiségi többségü területek külföldre kerülésével az etnikai alapú területi autonómia kérdése (egy-két járási nagyságú, baranyai-tolnai német többségü terület kivételével) a magyar állam számára gyakorlatilag megszünt.

A Párizs környéki békékben (1919-1920) a döntéshozók a soknemzetiségü, hatalmas kiterjedésü Osztrák-Magyar Monarchia, illetve a történelmi magyar állam romjain (a kisállammá zsugorított, etnikailag szinte homogénné tett Ausztria és Magyarország mellett) közepes méretü, de szintén soknemzetiségü országokat (pl. Csehszlovákia, Románia, SzerbHorvát-Szlovén Királyság) hoztak létre (5.ábra). A nem németek és nem magyarok együttes aránya az 51,4 millió lakosú Monarchiában 1910-ben 57,1\%-ot ${ }^{10}$ jelentett, míg az új (ill. megnagyobbodott) államok közül a nem uralkodó nemzetek és kisebbségek együttes aránya 1921 körül a következő volt: a nem cseheké Csehszlovákiában 50,1\%, a nem románoké Romániában 30\%, a nem szerbeké az S-H-S Királyságban 63,9\%. ${ }^{11}$ Az a tény, hogy a csehek, románok és szerbek által irányított államokhoz közel 20 millió kisebbségi lakos ${ }^{12}$ került, rávilágít arra, hogy az említett országok határainak kijelölésénél a népek önrendelkezési elvét, az etnikai elvet fölülírták a győztes államok és szövetségeseik stratégiai, katonai, gazdasági érdekei (Macartney, C.A. 1937).

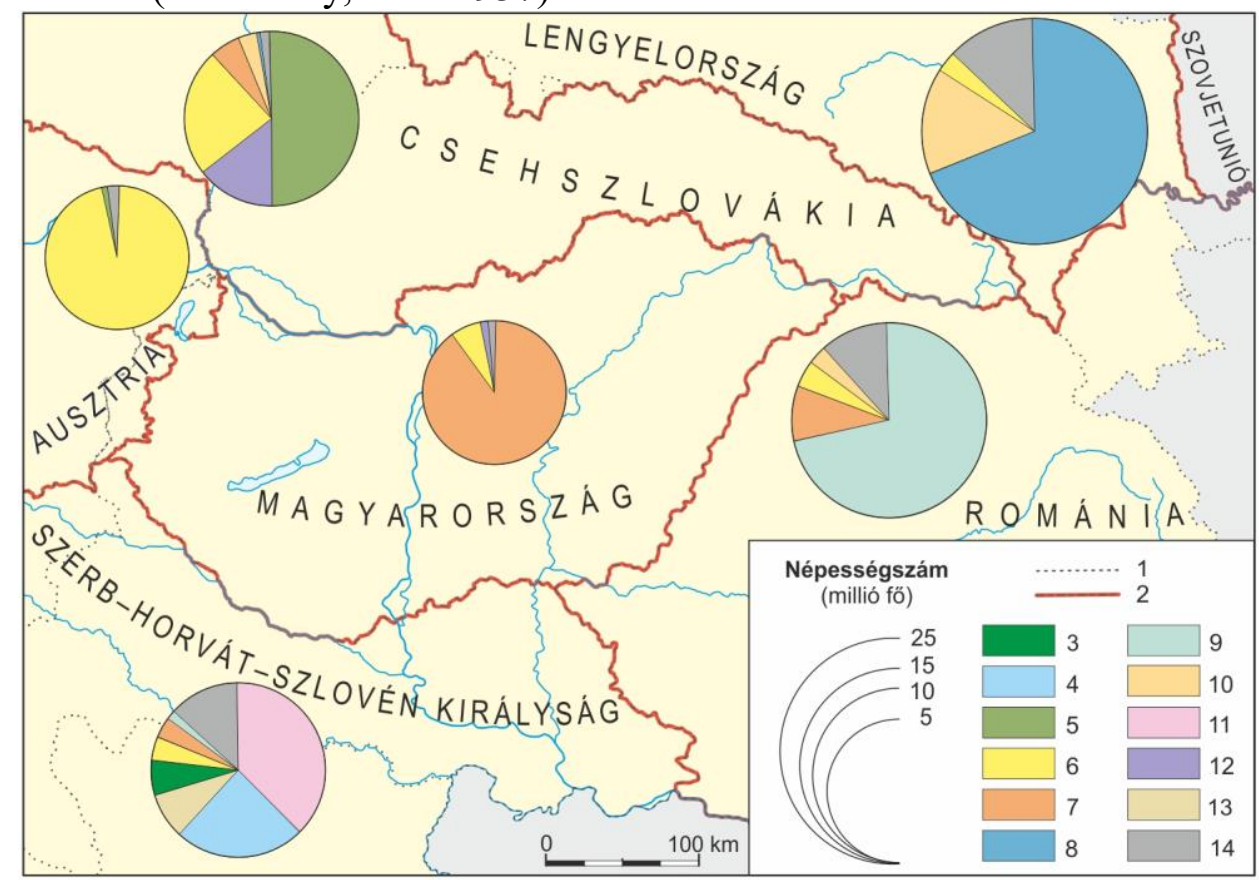

5.ábra Az Osztrák-Magyar Monarchia utódállamai népességének etnikai összetétele (1921) 1 = államhatár (1914); 2 = államhatár (1924); 3 = bosnyákok; 4 = horvátok, bunyevácok, sokácok; $5=$ csehek; $6=$ németek; 7 = magyarok; $8=$ lengyelek; 9 = románok; $10=$ ruszinok, ukránok; $11=$ szerbek; $12=$ szlovákok; $13=$ szlovének; $14=$ egyéb etnikai csoportok

A háborúból vesztesként kikerülő Magyarország új határainak kijelölésénél a nyelvhatárok (horvát és osztrák viszonylattól eltekintve) semmiféle szerepet nem játszottak. $\mathrm{Az}$ etnikai önrendelkezési elv is csak olyan mértékben volt fontos a döntéshozók

\footnotetext{
${ }^{10}$ Amennyiben csak a politikailag ténylegesen domináns helyzetben lévő ciszlajtániai német ajkúak, a magyarországi magyarok és a horvát-szlavónországi horvátok együttes arányát számítjuk, ez az érték 1910-ben $58,1 \%$ volt.

${ }^{11}$ A cseh irányítású Csehszlovákiában a nem „csehszlovákok” aránya 35,6\%-ot, a nem délszlávoké a „,nagyszerb” S-H-S Királyságban 17,1\%-ot ért el az 1921-es népszámlálások adatai szerint.

12 1921-ben az S-H-S Királyságban (12 millió lakos), Romániában (16 millió lakos) és Csehszlovákiában (13,6 millió lakos) a nem szerbek, nem románok és nem csehek lélekszáma 19,8 millió volt.
} 
szempontjából, hogy lehetőleg minél kevesebb nem magyar maradjon magyar fennhatóság alatt és a Kárpát-medencei szlovákok, románok és délszlávok túlnyomó része Csehszlovákia, Románia és az S-H-S Királyság határai közé kerüljön. Ezen elveken túl a szomszédos államok gazdasági, katonai érdekei határozták meg az új magyar határvonal kijelölését: a hegyvidéki szlovák, ruszin, román, szerb lakosság élelmiszer (föként kenyérgabona) ellátásában meghatározó szerepet betöltő, döntően magyarlakta alföldi területek; továbbá a győztesek határ menti, egymás közötti /Magyarországot elkerülö/ kommunikációjában kiemelkedő fontosságú vasútvonalak ${ }^{13}$ elcsatolása; katonailag jól védhető, természeti objektumokhoz (pl. folyók, hegygerincek) ${ }^{14}$ igazodó államhatár kialakítása; az államhatárnak a fövárostól (pl. Belgrádtól) való távoli kijelölése (Edvi I. A. - Halász A. 1920). Ezen szempontoknak a trianoni békediktátum során való érvényesítése (3,3 millió magyar anyanyelvü és lakóhelyének /többek között a Székelyföld, a Pozsonytól Szabadkáig 10-60 km szélességben húzódó, szinte homogén magyar etnikai terület elcsatolása) eredményeként született meg a jelen témánk szempontjából 1920 után fontos szerepet játszó Kárpát-medencei „magyar kérdés”.

A magyar revizionizmussal szemben 1920-21-ben a ,kisantant” nevü szövetségbe tömörült utódállamok első alkotmányaikban egy és oszthatatlan nemzetállamoknak nyilvánították magukat és a soknemzetiségü országaik széthullásától való félelmükben a kisebbségek mindenféle kollektív jogainak érvényesítését (elsősorban az etnikai alapú területi autonómiára vonatkozókat) megtagadták. Központosító, etnikailag homogenizáló, asszimilációs politikájuk eredményeként nemhogy „helvetizálták” („svájciasították”, etnikai alapú kantonokba, autonóm régiókba szervezték) volna olykor etnikai mozaiknak tekinthető országrészeiket, hanem hozzáláttak a (többnyire magyar) múltból örökölt közigazgatási területi struktúra (tartomány, megye, járás határok) olyan átalakításához, hogy a „megbízhatatlan” etnikai kisebbségek (főként a magyarok) az új közigazgatási egységekben mindenhol (vagy minél több helyen) kerüljenek kisebbségbe (ha lehet úgy, hogy még a hivatalos nyelvhasználati joghoz szükséges $20 \%$-os arányt se érjék el). Ilyen, etnikailag manipulatív (a magyar etnikai településterületeket közigazgatásilag szétziláló) terület felosztási reform lépett életbe Csehszlovákiában 1923-ban és 1927-ben, az S-H-S Királyságban 1923-ban és 1929-ben, Romániában 1925-ben, majd 1938-ban (Kocsis K. 1993, 2002, Molnár J. 1992).

Az elcsatolt, határvidéki magyar etnikai területek sorsának rendezését Magyarország és az utódállamok magyar kisebbségeinek vezetői alapvetően a területi revízióban (Magyarországhoz való visszacsatolásban), az államhatárok megváltoztatásában remélték, de a két világháború közötti időszakban magyar részről felmerültek az etnikai alapú (magyar) területi autonómiára vonatkozó tervek is (Rónai A. 1937, Szvatkó P. 1937, Bárdi N. 2004, Molnár M. 2009).

A központosított csehszlovák és délszláv államban a „társnemzeteknek” ígért széles körü területi autonómia sem valósult meg 1918 és 1938 között, melyért különösen a szlovákok és horvátok folytattak ádáz politikai küzdelmet. A történelmi Magyarország északkeleti hegyvidéki részén élő ruszinokat a csehek nem tekintették ugyan társnemzetnek, de lakóhelyükre az új Csehszlovákiának stratégiai szüksége volt, ${ }^{15}$ melynek érdekében az 1919. szeptember 10-i békeszerződésben (a Párizs környéki békékben egyedülálló módon)

\footnotetext{
${ }^{13}$ A hivatkozott főbb vasútvonal szakaszok a következők: Losonc-Feled-Bánréve-Rozsnyó; Torna-Szepsi-KassaSátoraljaújhely-Csap-Beregszász-Királyháza-Szatmárnémeti-Nagykároly-Nagyvárad-Nagyszalonta; KürtösArad; Horgos-Szabadka-Zombor.

${ }^{14}$ A hivatkozott főbb vízrajzi objektumok a következők: Dráva, Duna, Ipoly, Ronyva.

${ }^{15}$ Kárpátalja megszerzésére Csehszlovákiának Magyarország és Lengyelország szétválasztása és a magyarellenességben szövetséges Romániával való közvetlen kapcsolatának megvalósítása miatt volt elsősorban szüksége (Fedinec Cs. 2001).
} 
még azt is vállalta, hogy Kárpátaljának (Podkarpatska Rus) széles körü területi autonómiát ígérjen (Pop I. 2005). A szlovák és ruszin területi autonómia megvalósítását Csehszlovákia (két évtizedig) az utolsó pillanatig, 1938 októberéig halogatta, miután 1938. szeptember 29-én a müncheni egyezményben a német többségü Szudétavidéket, majd 1938. október 2-án a lengyel többségü, sziléziai Olzavidéket (Zaolzie) már elveszítette. ${ }^{16}$

A szlovák és ruszin területi autonómia kivívása, a német illetve lengyel többségü területeknek Német- és Lengyelországhoz való csatolása - a sikertelen komáromi magyarcseh-szlovák tárgyalások ${ }^{17}$ - után, 1938. november 2-án került sor az első bécsi döntésre, ahol Cseh-Szlovákia $11.927 \mathrm{~km}^{2}$ kiterjedésü, túlnyomóan magyarlakta, általa 1919-ben elfoglalt területet adott vissza Magyarországnak. ${ }^{18} \mathrm{~A}$ fenti események, az államhatároknak a nyelvhatárokhoz való igazítása eredményeként Cseh-Szlovákia közel került ahhoz, hogy etnikai értelemben immár joggal hívhassa magát a csehek, szlovákok és ruszinok együttes nemzetállamának. A két évtizedes autonómia küzdelmük során a csehekben csalódott szlovákokat és ruszinokat a területi autonómia már nem elégítette ki. A hitleri Németország agresszív, világháborút kirobbantó külpolitikájának megfelelően, annak támogatásával 1939. március 14-én megtörtént a Szlovák Köztársaság és Kárpát-Ukrajna függetlenségének kikiáltása, mely a cseh-szlovák állam felbomlását jelentette, majd másnap a maradék cseh országrészek német megszállását eredményezte (Fedinec Cs. 2002). Ezt követő két hét alatt lezajlott a csehek által 1919-ben elfoglalt $12.146 \mathrm{~km}^{2}$-nyi (672 ezer, 3/4 részben ruszin lakosságú) kárpátaljai és kelet-szlovákiai területnek - Németország által eltürt - magyar visszafoglalása, a közös magyar-lengyel államhatár létrehozása (Thirring L. 1939).

A horvátok az Osztrák-Magyar Monarchia magyar felében (Transleithania, Magyar Birodalom) élvezett széles körü területi autonómiájukat (Horvát-Szlavónország) az 1918. december 1-én létrejött, szerb irányítású $\boldsymbol{S}-\boldsymbol{H}-\boldsymbol{S}$ Királyságban elveszítették. Ennek megfelelően a két világháború között elkeseredett küzdelmet ${ }^{19}$ folytattak a szerb szupremáciával szemben, az elvett területi autonómiájuk, egyenrangúságuk visszaszerzéséért (Csuka J. 1995). A szomszédos Ausztria német bekebelezését (1938.03.12.), Csehszlovákia felbomlását (1939.03.14.) és Albánia olasz lerohanását (1939.04.07.) követően, a II. világháború előestéjén, az utolsó pillanatban sikerült az egyre inkább elszigetelődő Belgrádnak a horvátokkal megegyeznie (Cvetković-Maček egyezmény, 1939.08.24.) ${ }^{20}$ és megadni nekik az 1918-ban elveszített autonóm Horvát-Szlavónország helyett az immár Dalmáciát és Nyugat-Hercegovinát is magában foglaló autonóm Horvát Bánságot (Banovina Hrvatska, $65.456 \mathrm{~km}^{2}, 4$ millió lakos), mely Jugoszlávia horvátjainak 88\%-át tömörítette. ${ }^{21} \mathrm{~A}$

\footnotetext{
${ }^{16}$ Szlovákia autonómiáját Zsolnán 1938. október 6-án kiáltották ki, az autonóm Kárpátalja kormányának kinevezéséhez a prágai kormány pedig 1938. október 11-én adta beleegyezését. A két tartomány autonómiájáról szóló alkotmánytörvényt a cseh-szlovák kormány 1938. november 22-én hagyta jóvá (Fedinec Cs. 2002). ${ }^{17} \mathrm{Az}$ 1938. október 9. és 22. közötti komáromi tárgyalásokon a cseh-szlovák delegáció október 12.-én 1.800 km², október 13.-án $5.405 \mathrm{~km}^{2}$, október 22.-én $11.300 \mathrm{~km}^{2}$, 1919-ben elfoglalt terület visszaadását ajánlotta fel Magyarországnak. Jóllehet ez utóbbi ajánlat a bécsi döntőbírósági ítélet 95 \%-át képezte, de Pozsony, Nyitra, Léva, Rimaszombat, Kassa, Ungvár, Munkács, nyelvhatár menti, kiemelkedő fontosságú városok hovatartozásával kapcsolatos nézeteltérések megakadályozták a közös megegyezést. Ennek megfelelően Bécsben a német és olasz döntéshozók (Ribbentrop és Ciano) tulajdonképpen csak a néhány vitás város hovatartozásáról döntöttek, hiszen a túlnyomórészt magyarlakta rurális térség visszaadását maga Cseh-Szlovákia ajánlotta fel 1938. október 22-én (Rónai A. 1989. pp.166-181).

${ }^{18}$ A visszaadott területen 1.041.401 lakos élt, akiknek 84,4\%-a vallotta magát magyarnak, 11,9\%-a szlováknak (Az 1938. évi felvidéki nép-, földbirtok- és állatösszeírás. Magyar Statisztikai Közlemények, Új sorozat 108. MKKSH, Budapest).

${ }^{19}$ Ez a küzdelem Stjepan Radić (Horvát Parasztpárt/HSS elnöke) megölését (1928) követően oly méreteket öltött, mely a szerb királyi diktatúra bevezetéséhez, még fokozottabb nemzeti elnyomáshoz vezetett.

${ }^{20}$ Az egyezmény 1939.08.26-án vált királyi kormányrendeletté (Politika 11. 220 /27.08.1939/2.p).

${ }^{21}$ A Horvát Bánság népessége az 1931-es jugoszláv népszámlálás adatai szerint 4.007.227 fő volt, akiknek 69,8\%-a volt horvát, 18,9\%-a szerb, 3,6\%-a bosnyák. Az anyanyelvi és vallási adatokból számított etnikai kategóriák: horvát= római katolikus szerb-horvát anyanyelvü, szerb=ortodox/pravoszláv szerb-horvát
} 
két évtizedes ádáz politikai küzdelemben a szerbekkel való együttélésből kiábrándult horvátokat már nem elégítette ki a területi autonómia, melyet a teljes függetlenség felé vezető út első mérföldkövének tekintettek.

A II. világháború során, Franciaország német elfoglalása, Besszarábia szovjet birtokbavétele (1940.06.28.) után stratégiailag meggyengült Románia és a területi revíziók miatt erősebbé vált Magyarország között, az erdélyi kérdés miatt háborús konfliktus alakult ki. A sikertelen Turnu Severini tárgyalások (1940.08.16-24.) után, a magyar-román háború elkerülése érdekében a náci Németország és Olaszország felajánlotta a döntőbíráskodást, melyet a román, majd a magyar fél is elfogadott (Rónai A. 1989). A második bécsi döntés (1940.08.30.) értelmében Románia az általa 1918-19-ben elfoglalt területek közül 43.104 km²-nyi területet („Észak-Erdély”) adott vissza Magyarországnak (Thirring G. 1940). Erdély megosztása eredményeként a magyar fél 2,6 millió lakost (csaknem 1,3 millió nem magyart) kapott, míg a román fél 3,3 millió lakost (közülük 1,1 millió nem románt) tarthatott meg (Varga E. Á. 1992). ${ }^{22}$

1941. március 27.-én, a németbarát és a háromhatalmi egyezményhez csatlakozott Cvetković-kormányt megdöntő államcsínyt követően Hitler elrendelte Jugoszláviának a szomszédok bevonásával történt elfoglalását. A német és olasz csapatok 1941. április 6-án kezdték meg a politikai szempontból rendkívül labilis helyzetü ország viszonylag gyors lerohanását, mely hivatalosan az április 17-i szerb fegyverletétellel fejezödött be. Közben április 10-én Ante Pavelić horvát usztasa poglavnik (nemzetvezetö) Zágrábban kikiáltotta a Független Horvát Államot (NDH), ${ }^{23}$ mely Jugoszlávia felbomlását jelentette. A Szerémség, Bánság és Szerbia németek által történt elfoglalásának napján (április 11.) a magyar csapatok bevonultak a gyakorlatilag senki földjévé vált, a szerb csapatok által 1918-ban elfoglalt, magyar relatív többségű Baranyába és Bácskába. A tengelyhatalmak 1941. április 24.-i bécsi konferencián osztották fel az elfoglalt Jugoszlávia területét. Magyarország megtarthatta a visszafoglalt Bácskát és Baranyát, valamint megkapta az 1919-ben elveszített szlovén többségü Muravidéket és a szinte teljes egészében horvátok lakta Muraközt. Ezzel Magyarországhoz $11.475 \mathrm{~km}^{2}$-nyi, egymilliónyi (39\%-ban magyar) lakosságú terület tért vissza (Schneider Á. 1941, Fogarasi Z. 1944) (6.ábra). ${ }^{24}$ A volt dél-magyarországi Bánság jugoszláviai része - részben a várható magyar és román katonai összeütközést megelőzendő német katonai igazgatás alá került, elméletileg Szerbia részeként.

anyanyelvü, bosnyák=muzulmán szerb-horvát anyanyelvü. Forrás: Die Gliederung der Bevölkerung des ehemaligen Jugoslawien nach Muttersprache und Konfession nach der unveröffentlichten Angaben der Zählung von 1931. Publikationsstelle, Wien, 1943.

${ }^{22}$ Az 1941-es (1930-as) népszámlálások szerint a magyarok és románok aránya a következőképpen alakult: Észak-Erdélyben 52,1\% (42,1\%) magyar, 41,5\% (48,7\%) román anyanyelvü; Dél-Erdélyben 68,3\% (64,3\%) román, 10,9\% (14\%) magyar etnikumú (Varga E. Á. 1992).

${ }^{23}$ A Független Horvát Állam területe $102.725 \mathrm{~km}^{2}$-re (föként a történelmi Horvát-Szlavónországra, BoszniaHercegovinára és Dalmácia olaszok által meg nem szállt részére) terjedt ki. 5,6 milliónyi lakosságából 52,5\% volt római katolikus (túlnyomórészt horvát), 32\% ortodox (szerb) és 13\% muzulmán (bosnyák) (Klemenčić. M. 1992).

${ }^{24}$ A visszatért délvidéki terület (1.030.027 főnyi) népességének anyanyelvi megoszlása a következő volt: $39 \%$ magyar, 17,2\% német, 15,4\% szerb, 10,3\% horvát, 6,3\% szlovén, 6,1\% bunyevác (Fogarasi Z. 1944). 


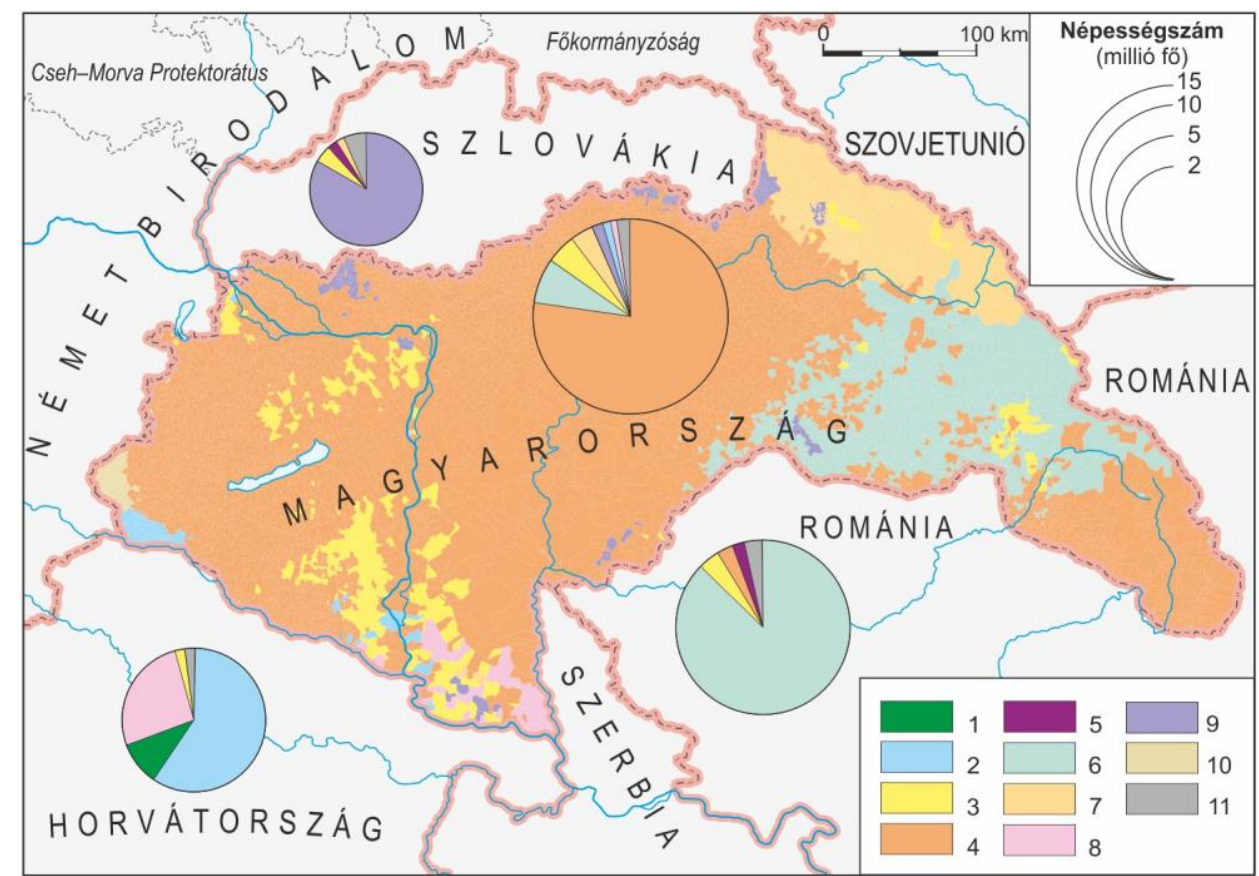

6.ábra Magyarország és szomszédságának etnikai térképe (1941)

1 = bosnyákok; 2 = horvátok, bunyevácok, sokácok; 3 = németek; 4 = magyarok; 5 = zsidók (etnikai értelemben); $6=$ románok; 7 = ruszinok; $8=$ szerbek; 9 = szlovákok; $10=$ szlovének; 11 = egyéb etnikai csoportok

Az 1938-1941 közötti területi revíziók eredményeként a Magyar Királyságnak sikerült az 1918 után elveszített területeinek 41,5\%-át visszaszereznie, mellyel kiterjedése 171.753 $\mathrm{km}^{2}$-re, népességszáma 14,7 millióra nőtt. ${ }^{25}$ A területnövekedéssel sikerült ugyan a Kárpátmedencei 12 milliónyi magyarság ${ }^{26} 95,2 \%$-át a magyar államon belül tömöríteni, de ennek az volt az ára, hogy a kisebbségek aránya 1930 és 1941 között Magyarországon 7,9\%-ról 22,5\%ra, lélekszáma közel 3,3 millióra nőtt (Fogarasi Z. 1944). Az ismét soknemzetiségűvé vált magyar állam csupán a több mint félmilliós ruszin kisebbség esetén fontolta meg (történelmi ${ }^{27}$ és földrajzi okok miatt) az etnikai alapú területi autonómia (Kárpátaljai Vajdaság) megvalósítását, melyet, mint törvénytervezetet a felterjesztő Teleki Pál miniszterelnök 1940. augusztus 5-én belpolitikai és katonai szempontok miatt visszavonni volt kénytelen (Fedinec Cs. 2001). A teljes körü autonóm státus helyett a Kárpátaljai Kormányzóság ${ }^{28}$ területén a magyar vármegyéktől független közigazgatási kirendeltségek jöttek létre, ahol a ruszint a magyar mellett második államnyelvvé tették (Botlik J. 2005).

\section{Az 1945 és 1989 közötti időszak}

A II. világháború végén, a frontátvonulásokat követő hatalomváltások után az 1938-1941 közötti területi revíziók érvényüket veszítették, melyet magyar vonatkozásban az 1947.

25 A Magyar Királyság (Horvát-Szlavónország nélküli) területe és lakossága 1910-ben 282.870,5 km², 18.264.533 fö, 1930-ban 93.073 km², 8.688.319 fö (Lökkös J. 2000), 1941 végén 171.753 km², 14.683 .323 fő (Thirring L. 1942, Fogarasi Z. 1944).

${ }^{26}$ Magyarok a Kárpát-medencében 1941 körüli népszámlálások szerint: Magyarország 11.365 ezer, román DélErdély 363 ezer, Bánság szerb része 102 ezer, Független Horvát Állam 59 ezer, Szlovákia 46,7 ezer, volt osztrák Burgenland 2 ezer (a szerbiai és horvátországi adatok a szerző becslései).

${ }^{27}$ Történelmi előzménynek a kárpátaljai ruszin területeknek a korábbi magyar és cseh-szlovák időszak legvégén, rövid ideig élvezett területi autonómiája számított: Ruszka Krajna (Magyarország, 1918.12.21-1919.03.20.), Kárpát-Ukrajna (Cseh-Szlovákia, 1938.10.11.-1939.03.14.).

${ }^{28}$ A Kárpátaljai Kormányzóság (Ungi, Beregi, Máramarosi közig. kirendeltségek) területe 11.583 km², 1941-beli lélekszáma 621.976 volt, közülük 77,4\% vallotta magát ruszin anyanyelvünek (Thirring L. 1942, Fogarasi Z. 1944). 
február 10-i párizsi békeszerződés szentesített. ${ }^{29}$ A háború idején náci vazallus Szlovákia és Horvátország függetlenségének megszüntetése árán 1945-ben újjáélesztették a cseh irányítású Csehszlovákiát és a szövetségi állammá átalakított Jugoszláviát. A ruszin-ukrán többségü Kárpátalját az 1945. június 29-i csehszlovák-szovjet megegyezés értelmében a Szovjetunióhoz csatolták. ${ }^{30}$ Az 1920-ban kijelölt magyar-román államhatárt visszaállították, majd a szovjet politikai zsarolás tárgyává tett, 1944. november 12/14. és 1945. március 9/13. között szovjet ellenörzés alá helyezett Észak-Erdélyben is helyreállt a román közigazgatás (Vincze G. 1994). ${ }^{31}$

A hatalomváltásokkal összefüggésben hatalmas méretü kényszermigrációk zajlottak le. Az evakuálás, elmenekülés és vérbosszú által megtizedelt német és magyar lakosságot Csehszlovákiában, Jugoszláviában és Romániában háborús bünbaknak, kollektív háborús bünösnek, a megszállók kiszolgálóinak tekintették, és azonnal megindult teljes, illetve részleges eltávolításuk (elüzésük, deportálásuk) föként a stratégiai jelentőségü határvidékekről (Kocsis K. 1992, 1999). ${ }^{32}$ A "kedvező" történelmi pillanatot kihasználva azonnal megindult a németek, magyarok helyére az adott ország államalkotó nemzetei tagjainak (pl. szlovákok, ukránok, románok, szerbek, montenegróiak) - föként az agrárreformok kereteibe ágyazott szervezett betelepitése, mely a (föként határvidéki és városi) népesség etnikai összetételének alapos átformálását, nemzeti-szociális célokat szolgált, és a jövőbeni esetleges újabb magyar területi revíziós követeléseket kívánta lehetetlenné tenni (Kocsis K. 1999). Az általános kisebbségellenes légkör és az "anyaországok" etnikai koncentrációs, homogenizációs törekvései következtében fokozódott a kisebbségeknek a nemzetállamaikba való migrációja, mely minden országban az államalkotó nemzet arányának tetemes növekedését, a korábban szinte homogén magyar népességü határvidéki területeken - a szlovák, ukrán, román, szerb kolonizáció révén - jelentős etnikai "felhígulást", az öshonos és jövevény lakosság tömeges keveredését, így az interetnikus feszültségek növekedését eredményezte. A kényszermigrációk ellenére a Magyarországgal szomszédos országok területén 1945 után is még körülbelül 3 millió fős, fele részben határvidéken élő magyar kisebbség maradt, akiknek településterülete vegyesebbé vált ugyan, de elvileg továbbra is lehetővé tette az etnikai alapú területi autonómia esetleges megvalósítását.

A Szovjetunió befolyása (többnyire katonai ellenőrzése) alá került Kárpát-medence országaiban (Ausztriát kivéve) 1945 és 1948 között szovjet típusú kommunista államigazgatási rendszerek épültek ki, melyek a későbbi évtizedekben is (az egyébként is kisebbségellenes közhangulatban) lehetetlenné tették az etnikai alapú, tényleges területi

\footnotetext{
${ }^{29}$ Az 1947. évi XVIII. törvény. A békeszerződés Oroszvár, Horvátjárfalu és Dunacsún községeknek a Pozsony biztonsága miatt aggódó Csehszlovákiához való csatolásával $65 \mathrm{~km}^{2}$-el tovább csökkentette a trianoni Magyarország területét.

${ }^{30}$ Az 1944 októberében szovjet megszállás alá került Kárpátalja a magyar fennhatóság megszűnte után - a nemzetközi jog szerint - ismét Csehszlovákia részévé vált ugyan, de már moszkvai forgatókönyv szerint megindult a terület szovjet bekebelezésének előkészítése. Egy átmeneti államalakulat (Kárpátontúli Ukrajna) nevében Munkácson 1944. november 26-án a helyi ukrán népi bizottságok kimondták a terület „újraegyesülését” Szovjet-Ukrajnával (Tóth I. 1993). A Kárpátontúli Ukrajna mint közigazgatási, ,állami” formáció léte 1946. január 22-én ért véget, amikor a Szovjetunió Legfelsőbb Tanácsának Elnöksége a szovjet Ukrajna részeként létrehozta a Kárpátontúli területet (Zakarpatszkaja oblaszty) (Oficinszkij, R. 2010).

${ }^{31}$ A sajátos állampolitikai vákuumban lévő, magyar igazgatás alatt már nem, román igazgatás alatt még nem álló Észak-Erdélyben a magyar lakosság a szovjet fennhatóság négy hónapja alatt jelentős lépéseket tudott tenni a még ma is csak remélt nemzeti önkormányzatiság felé (Molnár G. 1993). A román közigazgatás Észak-Erdélybe való visszatérését Sztálin a kommunista Petru Groza miniszterelnökké történt 1945. március 6-i kinevezése után engedélyezte (Vincze G. 1994).

32 A Kárpát-medencéből 1944 után kb. egymillió német „tünt el” (elmenekült, evakuálták, deportálták, megölték): pl. Vajdaságból és Horvátországból 336 ezer, a tágan értelmezett Erdélyből 274 ezer, Magyarországból 255 ezer, Szlovákiából 120 ezer (Kocsis K. 1992, Czibulka Z. et al. 2004). Az 1944-1950 között a szomszéd államokból Magyarország mai területére menekült, költözött, deportált magyarok száma 230300 ezer közötti lehetett (Stark T. 1989, Kocsis K. 1992).
} 
önrendelkezés megvalósítását. Ettől függetlenül meg kell említeni, hogy az 1945-ben „szövetségi népköztársaság” "33 formájában újjászülető, Josip Broz Tito vezette Jugoszlávia a területi decentralizációval, a köztársasági autonómiával, minden egyes délszláv nemzet (horvát, macedón, montenegrói, muszlimán/bosnyák, szerb, szlovén) identitásának, egyenjogúságának elismerésével és elvi garantálásával gyökeresen eltérő létfeltételeket biztosított az állam minden nem szerb etnikumának a két világháború közötti, központosított, szerb irányítású Jugoszláviához képest. Már a népfelszabadító háború idején (1943-ban) megígért autonóm tartományi státust a Vajdaság a kommunista Jugoszlávia megalakulása idején, 1945. november 29-én kapta meg. ${ }^{34}$ Regionális autonómiát a „Vajdaságnak” (1918-ig Dél-Magyarországnak, Délvidéknek) nevezett, közép-európai terület történelmi múltja, az itteni szerbek erőteljes regionális öntudata, sajátos kulturális különállása, etnikai tarkasága miatt kapott. Mindez persze nem jelentette az itteni kisebbségek (föként az akkor még 429 ezer fős ottani magyarok) etnikai alapú területi önkormányzatának megvalósulását, hiszen a kényszermigrációk következtében a Vajdaság 1945 után mát abszolút szerb többségűvé vált (1948: 50,6\%, 2011: 66,8\%). Maga a regionális autonómia is csupán az 1974. február 21-i új alkotmány után kezdett igazán (csaknem a tagköztársaságok önrendelkezésének szintjére) kiteljesedni (Strugar, V. 1976).

A Kárpát-medencében etnikai alapú területi autonómia a 20. század második felében, csupán egy rövid időre (1952-1960/68 között), Románia közepén jött létre. Szovjetunió (pontosabban Sztálin) amit az általa bekebelezett Kárpátalján nem valósított meg és Csehszlovákiától sem várt el, azt 1952-ben megkövetelte (a nem szláv és vele 1941-44 között hadban állt) Romániától: a magyar területi autonómia megvalósítását (Bottoni, S. 2008). Az 1952. szeptember 24-én elfogadott új román alkotmány Magyar Autonóm Tartomány (MAT) néven (szovjet utasításra, kényszerüségből) hozta létre ezt a $13.550 \mathrm{~km}^{2}$ kiterjedésü, Marosvásárhely székhelyü, 10 rajonból álló, 731 ezer (77\%-ban magyar) lakosságú közigazgatási egységet. ${ }^{35}$ A tartomány területe a történelmi Székelyföld ${ }^{36}$ magyarlakta részein kívül kiterjedt (gazdasági és közlekedés okok miatt) román többségü tájakra is (pl. Maroshévíz és Szászrégen közötti Maros-völgy, Görgény-vidék). A MAT ugyan magában foglalt 565 ezer magyart, de határain kívül rekedt az erdélyi magyarok 63,7\%-a (közel egymillió fö), akiknek kisebbségi jogai (a MAT létére való hivatkozással) egyre inkább sérültek, nyelvhasználatuk egyre jobban visszaszorult. A szovjet nyomás Sztálin halálát (1953) követő csökkenése, a levert 1956-os magyar forradalommal és szabadságharccal kapcsolatos erdélyi magyar szimpátia, feléledő, határon átívelő magyar nemzeti szolidaritás miatt a román kommunista nemzetállam egyre inkább fokozta a magyarokra nehezedő politikai nyomást és korlátozta a MAT jogkörét. 1960. december 24-én a tartomány átszervezése (és átnevezése: Maros-Magyar Autonóm Tartomány) során, gazdasági okokra hivatkozva Brassó tartományhoz csatolták a háromszéki magyar rajonokat, ugyanakkor ide kapcsolták a Marosvásárhely vonzáskörzetébe tartozó, román többségű Marosludas és

\footnotetext{
33 Tito az 1946. január 31-i alkotmányban a Jugoszláv Szövetségi Népköztársaságot (szovjet mintára) 6 köztársaságra (Szlovénia, Horvátország, Bosznia-Hercegovina, Montenegró, Macedónia és Szerbia) osztotta fel. A belső, köztársasági határokat túlnyomórészt a történelmi hagyományok alapján húzták meg néhány kivételtől eltekintve. Kivételnek számított a később vitásnak tekintett közös szerb-horvát köztársasági határ, melyet 1945ben két terület, Baranya (1948: 35,1\% horvát, 21,4\% szerb) és a Szerémség keleti és középső részének (1948: $70 \%$ szerb, 14,6\% horvát) cseréjével a Duna és a szerémségi szerb-horvát etnikai határ mentén jelöltek ki.

${ }^{34}$ A Szerbián belüli Vajdaság Autonóm Tartomány megalakítását a Demokratikus Szövetségi Jugoszláv Köztársaság jajcei megalakulása idején (1943. november 29.) határozták el, melyet pontosan két évvel később, ugyanott a kommunista Jugoszlávia szentesített.

${ }^{35}$ A MAT létrehozásáról formailag a 331/1952.IX.21-es törvényerejű rendelet gondoskodott. A tartomány lakosságának nemzetiségi megoszlása az 1956. február 21-i népszámlálás szerint: 731.387 összes lakos, 565.510 magyar $(77,3 \%), 146.830(20,1 \%)$ román, $11.108(1,5 \%)$ cigány.

${ }^{36}$ A Torda és Nagyenyed között elterülő, történelmi Aranyosszék természetesen nem volt része a MAT-nak.
} 
Dicsőszentmárton rajonokat (Elekes T. 2011) (7.ábra). A román nemzetállam az átszervezéssel nem csupán a tartomány területét és nemzetiségi összetételét ${ }^{37}$ alakította át a magyarok számára rendkívül hátrányos módon, hanem felgyorsította a „kulturális üvegházként" működő magyar területi autonómia intézményes hátterének elsorvasztását is (Bottoni, S. 2008). Az egyre inkább leplezetlenebbé vált román nemzetépítő, etnikai homogenizáló politika egyik állomásaként a formálissá vált (sokak szerint egyébként is csak nemzetiségpolitikai kirakatnak, magyar gettónak tekintett) autonóm tartományt a megyerendszert visszaállító törvény, 1968. december 19-i elfogadásával szüntették meg.

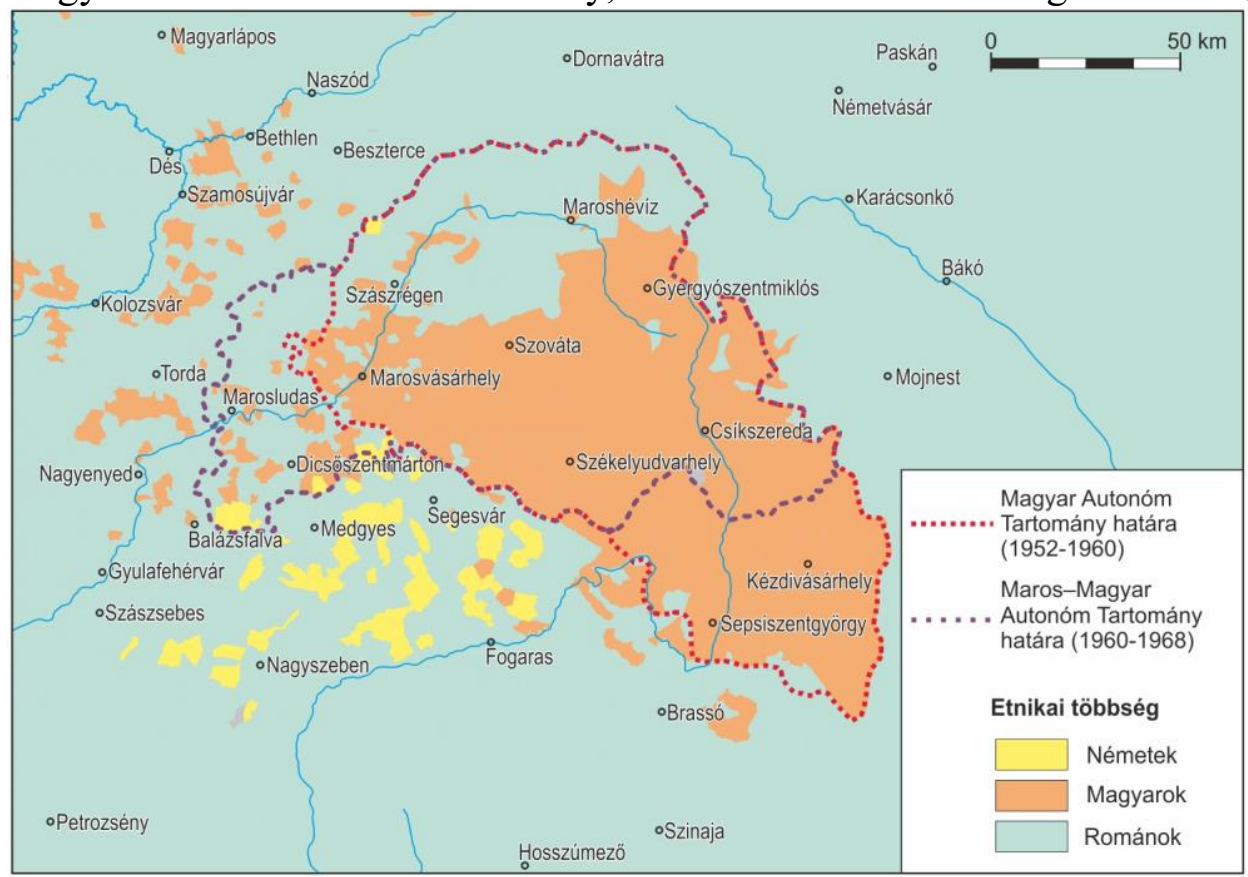

7.ábra A Maros-Magyar Autonóm Tartomány és környékének etnikai térképe (1966)

Jugoszlávia tényleges föderalista átalakítása, a szerb érdekek közvetlen érvényesítési lehetőségeinek beszükülése, Szerbia korábbi dominanciájának csökkenése - különösen Tito halálát (1980) követően - rendkívül megnövelte a privilegizált helyzetüket természetesnek tartó szerbek elégedetlenségét. Különösen sérelmezték, hogy az etnikai, történeti szempontból különleges helyzetü területek közül csupán a szerbiai Koszovó és Vajdaság tartományok kaptak autonómiát, de a horvátországi szerb többségü területek (pl. Krajina) nem. Mindezt a háborúban magukat győztesnek, békében vesztesnek tekintő szerbek nagy kudarcként élték meg. Így az 1980-as évek közepétől kezdve az 1974-es alkotmány elleni szerb támadás egyre hevesebbé vált. Slobodan Milošević vezetésével, a szerbek fenyegetettség-érzetének mesterséges felkeltése után „összszerb” mozgalom bontakozott ki, melynek eredményeként a szerb hatalmi koncentrációt szolgáló, ún. „,antibürokratikus forradalom” során, 1988-89-ben névlegessé tették (tulajdonképpen felszámolták) a Vajdaság ${ }^{38}$ és Koszovó autonómiáját.

\section{Az 1989 utáni időszak}

Európa volt szocialista országaiban, így a Kárpát-medencében is 1989-ban kezdődött a politikai, gazdasági, társadalmi rendszerváltás (rendszerváltozás), melynek során indult meg a kommunista rendszer lebontása és a nyugati típusú parlamenti demokráciák, a piacgazdaság

\footnotetext{
${ }^{37}$ Az 1960 végi átszervezés miatt változó területü tartományban a magyarok aránya az 1956. és 1966. évi népszámlálások között 77,3\%-ról 60,2\%-ra csökkent (a románoké 20,1\%-ról 36,8\%-ra nőtt).

${ }^{38}$ A Vajdaság autonómiáját az 1988. október 5-6-án, Újvidéken megszervezett államcsíny, ún. ,joghurt forradalom” után tették névlegessé (1989. július 5.).
} 
alapjainak lerakása. Ezen folyamat legfontosabb állomásának az 1990-ben megrendezett szabad, többpárt-rendszerü választások számítottak, melyek során (különösen az etnikailag vegyes összetételü országokban) az erős nemzeti retorikájú (sokszor nacionalista) pártok nagy sikert arattak (Weilguni, W. et al. 1991).

A volt szovjet érdekszféra országaiban lezajló, a rendszerváltás irányába mutató, egymást is erősítő események (pl. forradalmak, többpárti választások, politikai-gazdasági rendszer átalakításának megkezdése, szövetségi tagállamok függetlenedési törekvései) nagy hatást gyakoroltak a jugoszláviai nemzetek, nemzetiségek politikai magtartására is. A volt kommunista körök internacionalista köntösüket hirtelen nacionalistára cserélve „nemzetmentő” politizálásba kezdtek. Az új, 1990. évi horvát alkotmány államalkotó nemzetnek már csak a horvátokat ismerte el, a korábbi társnemzetet, a szerbeket már nemzeti kisebbségként kezelte és nem tette lehetővé számukra (sem) az etnikai alapú területi autonómia létrehozását (Silber, L.-Little, A. 1995). A felháborodott, Szerbia által manipulált horvátországi szerbek az autonómiáról történt népszavazásuk után 1990. szeptember 30-án kikiáltották a Knin székhelyü Krajinai Szerb Autonóm Területet (SAO Krajina), akkor még a Jugoszláviához tartozó Horvátország keretein belül. A szerb-horvát konfliktus eszkalálódásával, háborúvá fajulásával a szerbek 1991. április 2-én jelentették be a Horvátországtól való elszakadást és a Szerbiához való csatlakozást, majd december 19-én kikiáltották a független Krajinai Szerb Köztársaságot (KSZK) (Dakić, M. 1994). A nem csupán a szüken vett Krajinát (többségében addig szerbek lakta Észak-Dalmácia, Lika, Kordun, Banovina/Banija), hanem Szlavónia egyes nyugati részeit és Horvátország Duna melléki területeit (Baranya, Nyugat-Szerémség) is magában foglaló, nemzetközileg el nem ismert szerb államalakulat Horvátország területének több mint negyedét $\left(\mathrm{kb} .15 .000 \mathrm{~km}^{2}\right)$ foglalta el (Baletić, Z. et al. 1994) (8.ábra). ${ }^{39}$ 1992-ben, rendkívül megkésve Horvátország felkínálta ugyan a krajinai szerbek számára (a Glinai és Knini járásokra kiterjedő) területi autonómiát, ${ }^{40}$ de azt akkor a terület birtokában a szerbek már nem tartották kielégítőnek. A horvát-szerb frontvonal többé-kevésbé változatlan maradt 1995. május elejéig, mikor a horvát hadsereg visszafoglalta a nyugat-szlavóniai Okučani vidékét („Bljesak” /villám/ hadmüvelet), majd 1995 augusztus 4-8. között Észak-Dalmácia, Lika, Kordun, Banovina (Banija) területét („Oluja”/vihar/ hadmüvelet), ahonnét több mint 200.000 szerb menekült Szerbia felé, akiknek egy kis része (az 1998-ig ENSZ-szerb ellenőrzés alatt maradt) Baranyában, KeletSzlavóniában és a Nyugat-Szerémségben települt le. ${ }^{41}$ Ezzel megszűnt a KSZK és a tömeges kényszermigrációk miatt teljesen szétzilálódott a horvátországi szerbek 1995-ig még etnikailag többnyire egységes településterülete és jövőbeli reménye egy etnikai alapú területi autonómiára.

\footnotetext{
${ }^{39}$ A szerbek által ellenőrzött területnek 1991-ben 549.083 (52,4\% szerb, 37,1\% horvát nemzetiségü) lakosa volt. A krajinai szerb hatóságok szerint 1993 júniusában a terület már csak 433.595 (91\% szerb, 7\% horvát) lakosnak adott otthont (Republika Srpska Krajina (specijalni prilog), Vojska /Beograd/, Br.11. mart, 1994).

${ }^{40}$ Az 1992.12.30-i, a megyerendszert visszaállító horvát közigazgatási reform kínálta fel a különleges önkormányzatot (autonómiát) a szerb többségü, Glina és Knin központú járásoknak (térségeknek), melyet az emberi jogokról, szabadságról és az etnikai, nemzeti közösségek, kisebbségi jogairól szóló alkotmánytörvény szavatolt: 1992.06.06. V. fejezet.

${ }^{41}$ A horvátországi szerbek száma (aránya) a háborús migrációk és az asszimiláció következtében 1991 és 2011 között 581.663-ról (12,2\%-ról) 186.633-ra (4,4\%-ra) zuhant.
} 


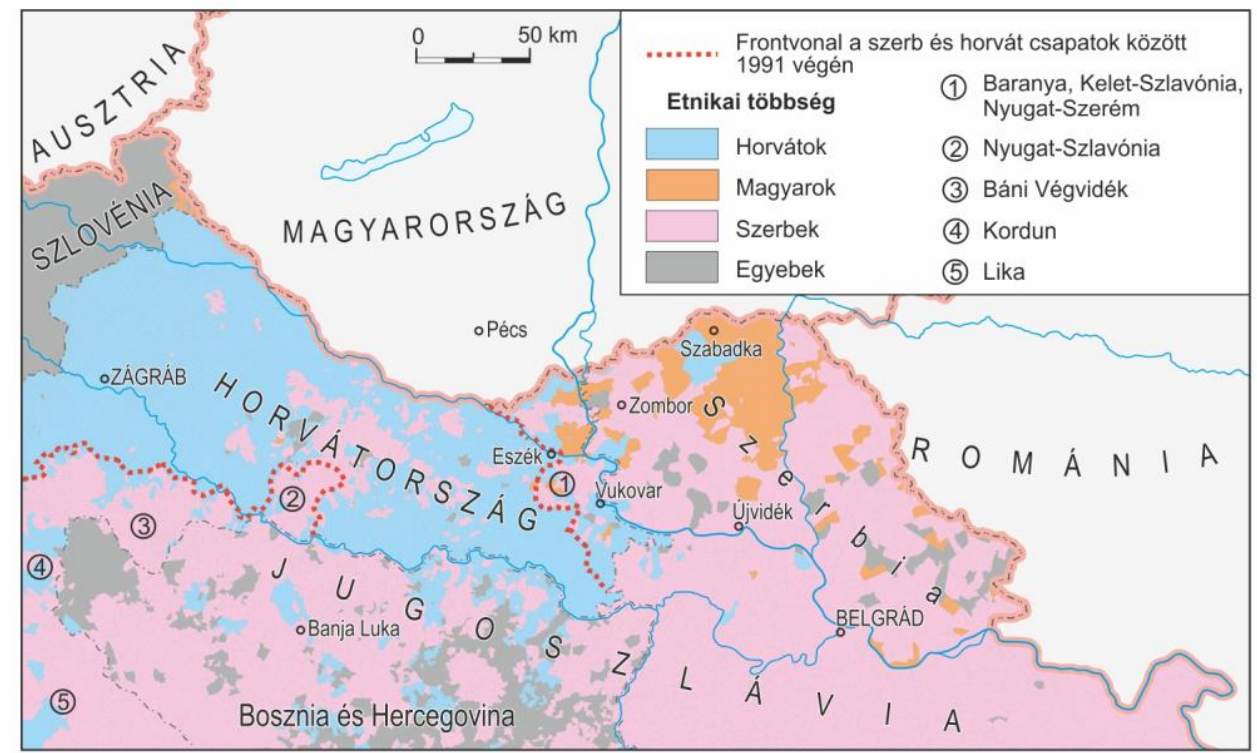

8.ábra Horvátország pannon területeinek etnikai térképe és a szerb-horvát frontvonal (1991) $1-5$ = A „Krajinai Szerb Köztársaság” részei

Szerbiában a miloševići rezsim a tartományi autonómiák névlegessé tételét az államhatalom olyan „,dekoncentrálásával” próbálta ellensúlyozni, mely a miniszterelnök által kinevezett vezetők irányította körzetek (okrug) ${ }^{42}$ 1991-es létrejöttét eredményezte (Jordan, P. 2010). A Vajdaságban hét (Belgrádból irányított) körzetet hoztak létre úgy, hogy a Tisza menti magyar etnikai területet közigazgatásilag háromfelé darabolták (Újvidék, Szabadka és Nagykikinda körzeteihez csatolták). Mellesleg ugyanígy jártak el a szandzsáki muzulmánok, bosnyákok etnikai területével is. Koszovó elvesztése és Milošević bukása után a szerb kormányok 2002-től fokozatosan megkezdték a Vajdaság 1988 után elveszett autonómiájának helyreállítását. A hat hivatalos nyelvvel rendelkező tartomány jelenleg is érvényben lévő, széles körü önkormányzatot biztosító alapokmánya 2010. január 1-től lépett életbe, melyet a szerb parlament 2009. november 30-án fogadott el. Az 1995-ös tömeges szerb menekülthullám miatt immár 2/3-ában szerb többségü tartomány autonómiájának helyreállítása a legnagyobb kisebbség, a vajdasági magyarok érdekét is szolgálta, de önazonosságuk megörzése érdekében már 1992-ben megalkották (a Vajdasági Magyarok Demokratikus Közössége) az etnikai alapú területi autonómiát is magában foglaló háromszintű önkormányzati modellt ${ }^{43}$ (Gerencsér B.-Juhász A. 2001, Surányi Z. 2001). A választási koalíciót alkotó magyar pártok a személyi elvü autonómia mellett továbbra is célul tüzik ki egy magyar többségű multietnikus régió, a Tisza közelében elhelyezkedő, magyar többségü nyolc község (opština) regionális önkormányzatának (Magyar Autonóm Körzet, Magyar Körzeti Önkormányzat) létrehozását (Surányi Z. 2001, Gábrity Molnár I. 2009). Ez a vajdasági magyarok közel 60\%-át tömörítö, tervezett autonóm körzet 327 ezer lakosú lenne, akiknek 53\%-a lenne magyar, 24,4\%-a szerb, 5,5\%-a horvát, 8\%-a ismeretlen nemzetiségü (2002). A területi autonómiát még nem, de a személyi elvü, széles körü kulturális

\footnotetext{
${ }^{42}$ A Belgrádot is magában foglaló 30 szerbiai okrug az 1991. július 24-i törvénynek köszönhette létét (Törvény a területi szerveződésről és helyi önkormányzatról).

${ }^{43}$ A VMDK magyarkanizsai kongresszusán (1992. április 25.) elfogadott „Memorandum a Szerb

Köztársaságban élő magyarok önkormányzatáról” szerint: 1. Személyi önkormányzat (vezető testülete a Magyar Nemzeti Tanács), 2. Területi önkormányzat (magyar többségü községek/opštinák együttese: Magyar Autonóm Körzet), 3. Helyi önkormányzat (az etnikai tömbön kívül lévő, magyar többségü települések önkormányzata).
} 
autonómiát $^{44}$ a vajdasági magyarságnak (a Kárpát-medencei jelentős lélekszámú magyar közösségek közül elsőként ${ }^{45}$ ) - föként a Vajdasági Magyar Szövetségnek köszönhetősen sikerült megvalósítania (Gábrity Molnár I. 2009, Korhecz T. 2009, 2010).

A kommunizmus bukása után a népes magyar kisebbségi közösségek nem csupán a soknemzetiségü hajdani Jugoszlávia területén, hanem a magát egységes nemzetállamnak tekintő, mai Ukrajna, Szlovákia és Románia területén is létrehozták önálló (kulturális, politikai) szervezeteiket ${ }^{46}$, melyek szinte azonnal megfogalmazták - önálló jogalanyiságuk kinyilvánításaként - különféle önrendelkezési, autonómia koncepcióikat (Ríz Á. 2000).

Kárpátalja még a Szovjetunió része volt, mikor a KMKSZ 1989-ben állást foglalt a Beregszász székhelyű magyar autonóm körzet létrehozásáról (Botlik J.-Dupka Gy. 1993). Ugyanakkor a tartomány őshonos szláv népessége, a szovjet fennhatóság idején önálló nemzeti létükben felszámolt, elukránosított ruszinok $^{47}$ (pontosabban a Kárpáti Ruszinok Társasága) megkezdték reménytelennek tünő küzdelmüket Kárpátalja (Kárpát-Ukrajna) 1938/39-ben élvezett autonómiájának helyreállításáért, mely helyi szinten is rendkívül heves vitákat váltott ki. Az alapvetően Ukrajna függetlenségek kérdésében kiírt 1991. december 1-i népszavazáson a helyi lakosság túlnyomó többsége Kárpátalján a terület különleges önkormányzati státusát $(78 \%)$, a Beregszászi járásban pedig a magyar autonóm körzet (MAK) létrehozását $(81,4 \%)^{48}$ is támogatta, de mindennek semmi politikai következménye nem lett, mert Kijev (a nacionalista erők nyomására) mindkét autonómia-törekvést mereven elutasította (Osztapec, J. 2010). A fiatal ukrán nemzetállam egységét az 1996. június 28-án elfogadott alkotmánya is kinyilvánította, mely orosz nyomásra csak a Krími Autonóm Köztársaság létét volt kénytelen elismerni. Az etnikai alapú területi autonómia ukrán elutasítása miatt a KMKSZ 2000-től kezdve egy olyan, Beregszász székhelyü Tisza-melléki járás (rajon) kialakítását kezdeményezi, ahol a magyarok alkotnák a lakosság többségét (72\%) úgy, hogy az a kárpátaljai magyarok 3/4-ét is magában foglalná. A szovjet időszakból származó, több mint fél évszázada változatlan határokkal létező járáshatárok megváltoztatásának egy esetleges, jövőbeli ukrán közigazgatási reform idején lehetne esélye, akkor is csak az etnikai szempontoknak a magyarok számára kedvező figyelembe vétele esetén.

A szlovákiai magyar pártok részéröl is több autonómia koncepció, törvénytervezet született meg az 1990-es években, melyek közül legkorábban (1991-ben) és legmarkánsabban az Együttélés Politikai Mozgalom fogalmazta meg a területi autonómia igényét. Ezek a törekvések a szlovákiai magyar képviselök és polgármesterek 1994. január 8-i komáromi nagygyülésén érték el csúcspontjukat és kaptak széles körü országos publicitást (Az

\footnotetext{
${ }^{44}$ A vajdasági magyar kulturális autonómia legfőbb letéteményese, az itteni magyarság országos kisebbségi önkormányzati szerve, a Magyar Nemzeti Tanács alapvetően a 2002. február 26-án elfogadott „A nemzeti kisebbségek jogainak és szabadságának védelméről” szóló törvénynek, a 2000 óta tartományi kormánypártnak számító Vajdasági Magyar Szövetség érdekérvényesítő képességének, a vajdasági (többnyire toleráns) politikai kultúrának, hagyományoknak, a többségi és kisebbségi politikusok között kialakult bizalmi viszonynak köszönheti létét (Korhecz T. 2009, 2010).

${ }^{45}$ Amennyiben a kis magyar közösségeket is számításba vesszük, kulturális autonómiával legrégebben a szlovéniai, muravidéki magyarság rendelkezik. Csúcsszervük a Muravidéki Magyar Önkormányzati Nemzeti Közösség (MMÖNK, 1989), melynek jogelödje 1975-ben jött létre (Gerencsér B.-Juhász A. 2001).

${ }^{46}$ A legelső, már 1989-ben létrejött magyar kisebbségi érdekvédelmi szervezetek a következők voltak: szovjet Ukrajnában a Kárpátaljai Magyar Kulturális Szövetség (KMKSZ, 1989. február 26.), Csehszlovákiában a Független Magyar Kezdeményezés (FMK, 1989. november 18.), Jugoszláviában a Vajdasági Magyarok Demokratikus Közössége (VMDK, 1989. december 18.), Romániában a Romániai Magyar Demokrata Szövetség (RMDSZ, 1989. december 25.) (Szarka L. 2008).

${ }^{47}$ A 2001-es népszámlálás idején Kárpátalján a lakosságnak már csak 0,8\%-a (10.090 fö) vallotta magát ruszin nemzetiségünek (1941-ben 58,9\% / 502 ezer ruszin anyanyelvü).

${ }^{48}$ A kárpátaljai magyarok közel 38\%-át tömörítő Beregszászon és járásában az 1989-es népszámlálás idején a lakosságnak csupán $66,9 \%$-a vallotta magát magyar nemzetiségünek.
} 
önkormányzat...1994, Gerencsér B.-Juhász A. 2001, Molnár M. 2009.). Az Együttélés itt bemutatott és jóváhagyott tervezete két változattal (egy összefüggő vagy három, magyar többségű régióval) számol, attól függően, hogy országosan kevés vagy nagyszámú régión nyugvó területfelosztás került volna elfogadásra a közelgő közigazgatási-területi reform során. Az első esetben egy $8245,3 \mathrm{~km}^{2}$ területü, a magyar államhatárhoz tapadó, kb. 824 ezer (61,5\%-ban magyar) lakosú régió ${ }^{49}$ jött volna létre (Oriskó N. 1993, Duray M. et al. 1994, Kocsis K. 2002). A második változat szerint a már ismertetett magyar többségü régió három részre oszlott volna: 1. Nyugaton Pozsony és Ipolyság között (525 ezer fö, 63,1\% magyar), 2. Középen Ipolyság és Kassa között (239 ezer fö, 54,2\% magyar), 3. Keleten Dél-Zemplénben és Ungvidéken (59 ezer fó, 77,3\% magyar). Az etnikai alapú területi autonómiára, közigazgatási reformra vonatkozó magyar tervekre mind a szlovák politika, mind a szlovák társadalom széles rétegei rendkívül éles elutasítással, olykor szinte hisztérikusan reagáltak (Bakker, E. 1997, Fazekas M. 2009). A magyar és cseh fennhatóság idején autonómiájukért, függetlenségükért több mint egy évszázadig küzdött szlovákok körében (részben a ruszinokhoz, ukránokhoz is hasonlóan) maga az autonómia szó, a belső területi önrendelkezésre való törekvés egyet jelent a függetlenség felé vezető út első állomásával, a nyílt állampolgári hütlenséggel, szecesszionizmussal. Ennek megfelelően nem hatott meglepetésként, hogy a Szlovák Nemzeti Tanács a "Szlovák Köztársaság területiközigazgatási rendjéröl" szóló 1996. évi 221.sz. törvényében olyan, ma is érvényes közigazgatási beosztást valósított meg, mely a magyar pártok elképzeléseinek szinte tökéletes ellentétét képezik. Az új kerület (kraj) és járás (okres) határok a dél-szlovákiai (rendkívüli irredenta veszélyforrásként kezelt) magyar településterületet teljesen széttagolták, annak érdekében, hogy a magyarok szinte minden közép- és magasabb szintü közigazgatási egység népességében kisebbségbe kerüljenek és ezáltal meghiúsítsák a magyar területi önkormányzati törekvéseket (Kocsis K. 2002, Hamberger J. 2008). Az 1998-ban kormánypárttá vált Magyar Koalíció Pártja (MKP) az új helyzetben, a politikai alkudozások eredményeként már lemondott az etnikai alapú területi autonómiáról, de kezdetben még törekedett a fentiekben ismertetett közigazgatási törvény felülvizsgálatára. Ennek során az Együttélés-féle tervhez képest már rendkívüli engedményeket téve csak egy "Dunamente (v. Komárom)" nevü, 602 ezer lakosú, 55,2\%-ban magyar többségü, Somorja és Ipolyság közötti, nyugati régió létrehozására törekedett. Az ország éléskamrájának számító, a bősi vízerőmünek és a mohi atomerőmünek is otthont adó, ezen magyar többségű régió tervét a szlovák kormány (csakúgy mint az ellenzéki nacionalista pártok) "szakmailag megalapozatlannak" és az egységes szlovák nemzetállam területi épségére nézve veszélyesnek tartották és mereven elutasították. Azóta a reménytelennek vélt magyar területi autonómia kérdése a szlovákiai magyar pártok részéről teljesen háttérbe szorult, a hangsúly inkább a civil kezdeményezésekre helyeződött át (Comorra Aula).

A Magyarország határain túli legnagyobb magyar közösség, az akkor több mint 1,6 milliónyi erdélyi magyarság a román forradalom végén, 1989. december 25-én hozta létre egységes érdekvédelmi szervezetét a Romániai Magyar Demokrata Szövetséget (RMDSZ). A rendkívül sokszínü mozgalomban 1992-re a kisebbségi jogokat Románián határozottan számon kérö, autonómiát nyíltan követelő, külföldi nyomásgyakorlás kedvező hatásában is bízó politikai irányzat kerekedett felül, mely a romániai magyarság társnemzeti státuszának, autonómiájának és a kisebbségi törvény követelésében is megnyilvánult (Bárdi N. 2008). Ekkor fogadták el a „Nyilatkozat a nemzeti kérdésről” címü dokumentumot (Kolozsvári

\footnotetext{
${ }^{49} \mathrm{Az}$ így eltervezett régió etnikai földrajzi szempontból sem számított egyedülállónak Európában, hiszen az olaszországi Trentino-Alto Adidge régió Dél-Tirol (Südtirol, Alto-Adidge) nevü, 430 ezer lakosú autonóm tartománya is NY-K-i irányban elnyúlt szalagként tapad az anyaországhoz (Ausztriához) és az itteni németek/osztrákok aránya a tartományon belül (64,9\%) kísérteties módon hasonlított az "Együttélés” által tervezett dél-szlovákiai régióban a magyarok arányához (61,5\%).
} 
Nyilatkozat, 1992. október 25.), mely az elmúlt két évtizedbeli erdélyi magyar autonómiatörekvések motorjának fogható fel (Bakk M. 2012). Ekkor készültek az első, háromlépcsős autonómia-modellek, melyek magukban foglalták a területi autonómia (a helyi magyar többségü önkormányzatok szabad társulásán alapuló „Magyar Nemzeti Közösségi Régió") igényét is (Csapó I. J. 2003, Gerencsér B.-Juhász A. 2001, Bognár Z.). Az 1996-ban kormányzati pozícióba került RMDSZ-en belül az autonómia elérését hosszabb folyamatnak tekintő „mérsékelt” és a „radikálisabb” (,,autonomista”) irányzat közötti konfliktusok 2003ban már oda vezettek, hogy az utóbbiak vezető egyéniségei kifejezetten a magyarság autonómia törekvéseinek közképviseletére létrehozták az Erdélyi Magyar Nemzeti Tanács (EMNT) nevü civil szervezetet, majd hasonló céllal, de már csak a Székelyföldre fókuszálva a „Székely Nemzeti Tanácsot (SZNT) ${ }^{50}$ A Székelyföld SZNT által 2003-ban kidolgozott autonómia statútumát 2004-ben a román képviselöház és szenátus is határozottan elutasította. A módosított, immár a kormány tagjának számító RMDSZ által újra, 2005-ben benyújtott, a Székelyföld autonómiájára vonatkozó törvénytervezetet a román képviselöház néhány hónap múlva, a szenátus 2012. szeptember 25-én utasította vissza. A tervezet szerint a „Székelyföld Autonóm Terïlet" $9.980 \mathrm{~km}^{2}$ kiterjedésü, nyolc székre osztott, ${ }^{51} 809$ ezer össznépességü, 76\%-ban magyarok által lakott régió lett volna, mely alapvetően a mai Hargita és Kovászna megyéket, illetve a mai Maros megyéböl jórészt a történelmi Marosszéket foglalta volna magában. ${ }^{52}$ A statútum parlamenti elutasítása után az SZNT 2006. december és 2008. február között - kezdeményezésének alátámasztására, de a hatóságok által törvénytelennek minősített - népszavazást szervezett a Székelyföldön, melynek eredményeként a szavazók 99,3\%-a mondott igent a régió területi autonómiájára. ${ }^{53} \mathrm{Az}$ erdélyi magyarság területi autonómiával kapcsolatos törekvését szokás a remélt székelyföldi autonómiával azonosítani és kevéssé ismert, hogy az EMNT támogatta egy Partiumra (föként Észak-Biharra, a Szilágyságra és Nyugat-Szatmárra) kiterjedő magyar autonóm terület tervének kidolgozását is (Szilágyi F.Csomortányi I. 2010). A magyar államhatárhoz tapadó, a románok szemében fokozott irredenta veszélyforrást is jelentő, jórészt magyar-román vegyes lakosságú régióra többféle terv készült, melyek közül a legnagyobb területü 349 ezer lakosnak (191 ezer, 54,5\% magyarnak és 130 ezer, 37,1\% románnak) adna otthont és magában foglalná Szatmárnémeti, Nagykároly, Szilágysomlyó illetve Margitta városokat is. A tervezet még nem került be a román köztudatba, egyelöre csak a partiumi magyarságot szoktatja a szülőföldjükön elképzelhetö területi autonómia gondolatához.

Az etnikai alapú területi autonómiatervekkel kapcsolatos sorozatos kudarcok következtében az RMDSZ az ország 1998-ban létrehozott tervezési régióinak átalakításával, a 2007-es EU-s parlamenti választások előtt tett javaslatot a Maros, Hargita és Kovászna megyéket egyesítő (tulajdonképpen egy székelyföldi) régió kialakítására (Csutak I. 2007, Szilágyi F. 2010). Javaslatát Románia közigazgatási átszervezésére 2010-ben létrehozott elnöki szakértői bizottsággal való tárgyalások idejére is fenntartotta (15 régió, ebből egy magyar többségü).

A romániai, ukrajnai és szlovákiai magyar autonómiatörekvések eddigi kudarca alapján elmondható, hogy mind a többségi nemzetnek, mind a magyar félnek változtatnia

\footnotetext{
${ }^{50}$ A területi autonómiáért nyíltan küzdő, mielőbbi eredményeket elérni kívánó MNT Tőkés László és Fejes Anzelm elnökletével 2003. április 25-én (Székelyudvarhelyen), az SZNT Csapó I. József elnökletével 2003. október 16-án (Sepsiszentgyörgyön) jött létre. Az RMDSZ-ből kiválók 2008-ban hozták létre a Magyar Polgári Pártot, 2011-ben az Erdélyi Magyar Néppártot.

${ }^{51}$ Kézdi-, Orbai-, Sepsi-, Csík-, Udvarhely-, Gyergyó-, Maros-, Miklósvár-Bardócszék.

52 Vonzáskörzeti megfontolások alapján a román többségü, hajdan Székelyföldhöz tartozó Bodza-vidéket a tervezők átengednék Brassó megyének, a székelyföldi múlttal nem rendelkező, román többségű Maroshévízt és környékét viszont a régióhoz csatolnák, csakúgy mint Szászrégen déli szomszédságában, illetve Baróttól nyugatra fekvő magyar településeket is (www.sznt.ro).

${ }^{53}$ A 461.566 szavazásra jogosult székelyföldi lakos közül 52,98\% vett részt a referendumon (www.sznt.ro).
} 
kellene az álláspontján. A román, ukrán, szlovák döntéshozóknak be kellene látniuk, hogy a területi autonómia nem merénylet a szuverenitás ellen és nem feltétlen vezet az elszakadáshoz, hanem sikeres müködése esetén az integráció és konfliktuskezelés egyik hatékony formája. A jelenleg súlyosan megosztott magyar kisebbségi politikusoknak is tudomásul kellene vennie, hogy az autonómia nem varázsszer, nem érhető el egyoldalú deklarációkkal, megvalósításához (többek között) a többségi nemzet felé való egységes fellépés, de ugyanakkor bizalmi légkör kialakítása, tehát hosszú idö, türelem, és politikai bölcsesség szükséges (Salat L. 2004).

\section{A Kárpát-medencei etnikai alapú területi autonómiák jelenlegi földrajzi lehetőségei}

Az etnikai alapú területi autonómiák (vagy legalább a nemzeti kisebbségek által többségében lakott helyi önkormányzatok regionális társulásainak) létrejöttéhez és sikeres müködéséhez a szükséges politikai feltételek, történeti hagyományok, szerencsés körülmények ${ }^{54}$ mellet a már jelzett etnikai földrajzi-demográfiai feltételek meglétére van szükség (a kisebbség a számbeli, demográfiai többség; településterülete viszonylag összefüggő és kellően nagy, gazdaságilag életképes). Ez utóbbi feltételeknek jelenleg csupán az előző fejezetben már említett szlovákiai, kárpátaljai, erdélyi és vajdasági magyar etnikai terület felel meg (9.ábra). Az egy évszázada még több százezres lélekszámú, Kárpát-medencei kisebbségek közül a kényszermigrációk miatt a németek (1944-50) és szerbek (1991-95) esetében ma már nem jöhet szóba az önrendelkezés ezen formája.

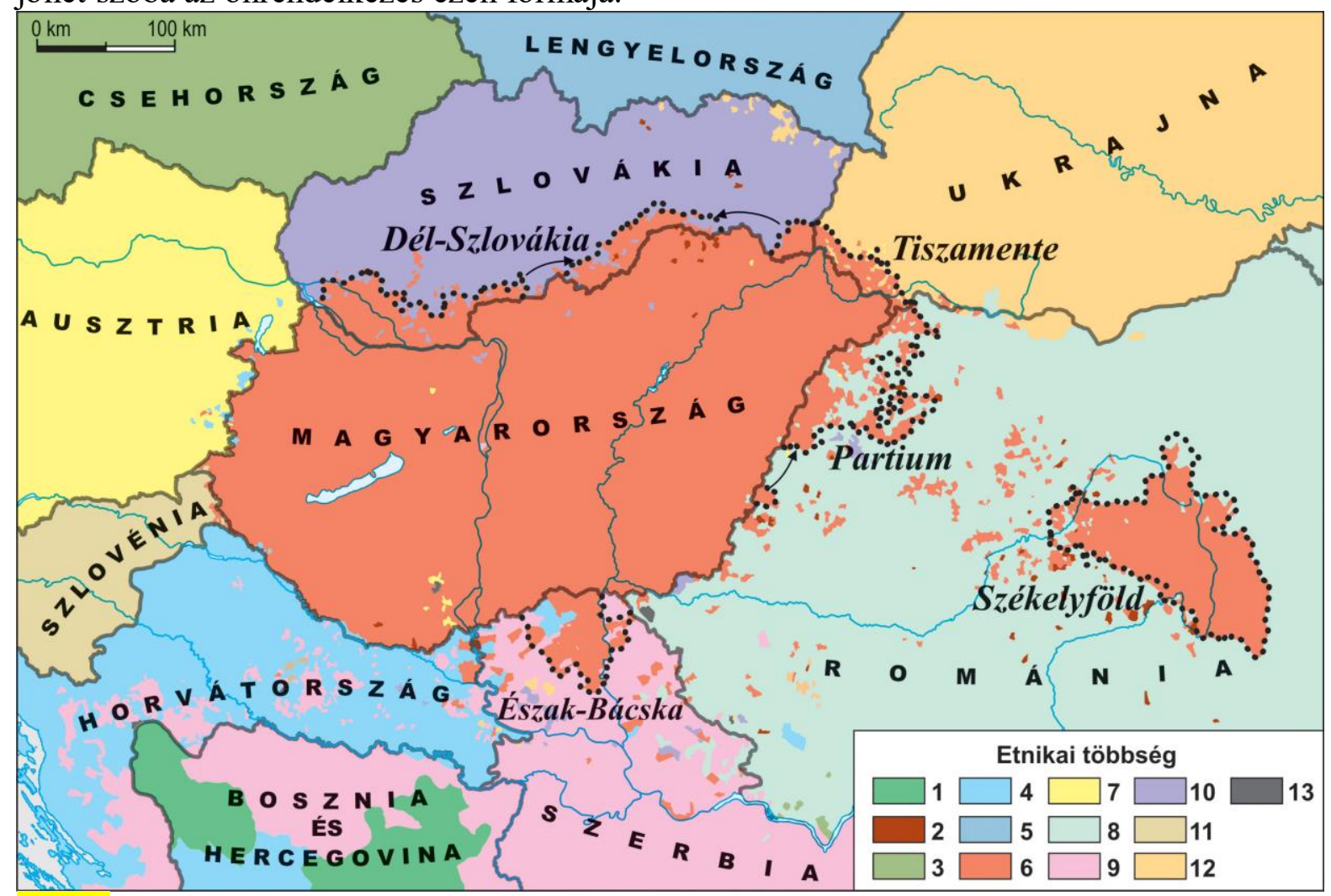

9.ábra Földrajzilag elképzelhetö etnikai alapú területi autonómiák a Kárpát-medencében

1 = bosnyákok, muszlimánok; 2 = horvátok, bunyevácok, sokácok; 3 = csehek; 4 = németek, német nyelvű osztrákok; 5 = magyarok; 6 = lengyelek; 7 = románok; 8 = cigányok, romák; 9 = szerbek; 10 = szlovákok; 11 = szlovének; $12=$ ukránok; 13 = egyéb etnikai csoportok

\footnotetext{
${ }^{54}$ Lsd. Ghai, Y. (2002)
} 
Szlovákia mai területén az elmúlt évszázadban a csehszlovák (1993-tól szlovák) nemzetállam építésével összefüggő kényszermigrációk, asszimilációs folyamatok és a magyarellenes közhangulat eredményeként folyamatosan csökkent a magukat magyarnak vallók, magyarként nyilvántartottak száma és aránya. ${ }^{55}$ Ettől függetlenül a magyarok túlnyomó többsége az ország déli területein, a magyar határ közelében többé-kevésbé összefüggő településterületet képez, ahol 2011-ben még 414 városban és községben alkották a helyi lakosság anyanyelvi többségét. Szlovákia jelenlegi 79 járása közül a feltünően magyarellenes közigazgatási reformok $(1960,1996)$ óta mindössze kettő magyar többségü (Komárom, Dunaszerdahely) (Kocsis K. 2002). A természetes vonzáskörzetek, ${ }^{56}$ a történelmi hagyományok és az etnikai viszonyok figyelembe vételével Szlovákiában jelenleg 16 olyan járás lenne kialakítható, ahol a magyar anyanyelvüek alkothatnák a lakosság többségét (10.ábra) ${ }^{57}$ Közülük már mindegyik volt az elmúlt évszázadban járási vagy megyeszékhely (Kocsis K. 2002). A szlovák-magyar határ közelében sorakozó ezen járások közül nyugaton 9, középen 5, keleten 2 alkothatna olyan társulást (,Dél-Szlovákiai Autonóm Régió”), melynek összlakossága meghaladná a 680 ezer föt, akik közül 63,5\% (432 ezer) lenne magyar, 27,9\% (190 ezer) szlovák, 1,6\% (11 ezer) cigány anyanyelvü (1.táblázat).$^{58}$ Ezen az elképzelhető régión kívül a szlovákiai magyaroknak mindössze 15\%-a maradna, akiknek jelentős része a szlovák-magyar nyelvhatár 1945-ig magyar, azóta dominánsan szlovák többségü városaiban (Szenc, Vágsellye, Léva, Losonc, Kassa) és Pozsonyban él.

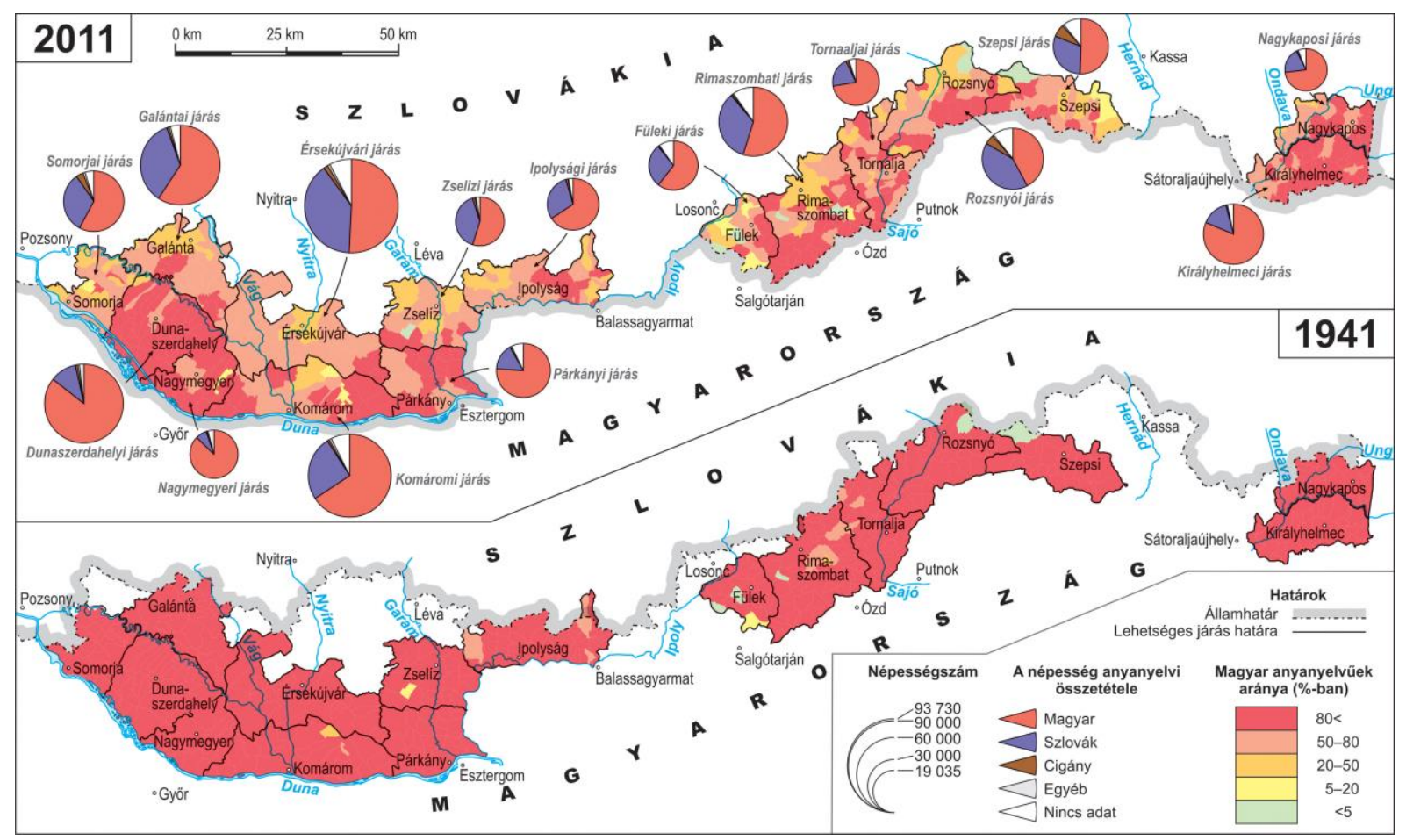

55 Szlovákia mai területén magukat magyarnak vallók száma (a: anyanyelv; n: nemzetiség): 1910-ben 880.851 (a), 1930-ban 585.434 (n), 1991-ben 567.296 (n), 2011-ben 458.467 (n).

${ }^{56}$ Michniak, D. 2006. Zázemia vybraných centier dochádzky do zamestnania v roku 2001. In: Atlas obyvatel'stva Slovenska, Univerzita Komenského, Bratislava, pp.78-79., Halás, M.-Klapka, P. 2012. Contribution to regional division of Slovakia based on the application of Reilly's model. Hungarian Geographical Bulletin 61. 3. pp. 237255 .

${ }^{57}$ Somorja/Šamorín, Dunaszerdahely/Dunajská Streda, Nagymegyer/Vel'ký Meder, Galánta/Galanta, Komárom/Komárno, Érsekújvár/Nové Zámky, Párkány/Štúrovo, Zselíz/Želiezovce, Ipolyság/Šahy, Fülek/Fil'akovo, Rimaszombat/Rimavská Sobota, Tornalja/Tornal'a, Rozsnyó/Rožňava, Szepsi/Moldava nad Bodvou, Királyhelmec/Král'ovský Chlmec, Nagykapos/Vel'ké Kapušany

58 1941-ben ezen a területen 571 ezer lakos élt, akiknek 95,5\%-a (545 ezer) volt magyar és 3,3\%-a (19 ezer) szlovák anyanyelvü. 
10.ábra Magyarok aránya a földrajzilag elképzelhetö Dél-Szlovákiai Autonóm Régió területén $(1941,2011)$

1.táblázat A népesség anyanyelvi összetétele a földrajzilag elképzelhető „Dél-Szlovákiai Autonóm Régió” területén (1941-2011)

Az ukrajnai Kárpátalján a magyarok száma az elmúlt fél évszázadban az elvándorlás ellenére sem csökkent drámai módon (1959: 146 ezer, 1979: 158 ezer, 2001: 152 ezer). A terület 13 járása közül a magyarok csupán a Beregszászi járásban képeznek többséget, ahol (Beregszász várossal együtt) a kárpátaljai magyaroknak csupán 35,6\%-a él. A természetes vonzáskörzeti és etnikai viszonyokat figyelembe véve szükséges lenne a 60 éve változatlan járáshatárokat felülvizsgálni és a magyar-ukrán határhoz simuló magyar településterületen indokolt lenne alapvetően az Ungvári járásból egy 49 ezer lakosú Csapi járást, a mai Nagyszőlősi járásból pedig egy 38 ezer lakosú Tiszaújlaki járást leválasztani (11.ábra). ${ }^{59} \mathrm{Az}$ így létrejövő három abszolút magyar többségü járás társulásával létrejövő terület (,, Tiszamenti Autonóm Körzet”) együttes népessége meghaladná a 165 ezer föt, akiknek 68,2\%-a lenne magyar, 25,5\%-a ukrán, 3,9\%-a cigány, 1,7\%-a orosz nemzetiségü (2.táblázat). Ezen járásokon kívül a kárpátaljai magyaroknak csupán negyede maradna, főként a magyar-ukrán nyelvhatár közelében fekvő városokban (Ungvár, Munkács, Nagyszőlős) és a FelsőTiszavidéken (pl. Visk, Técsö, Aknaszlatina).

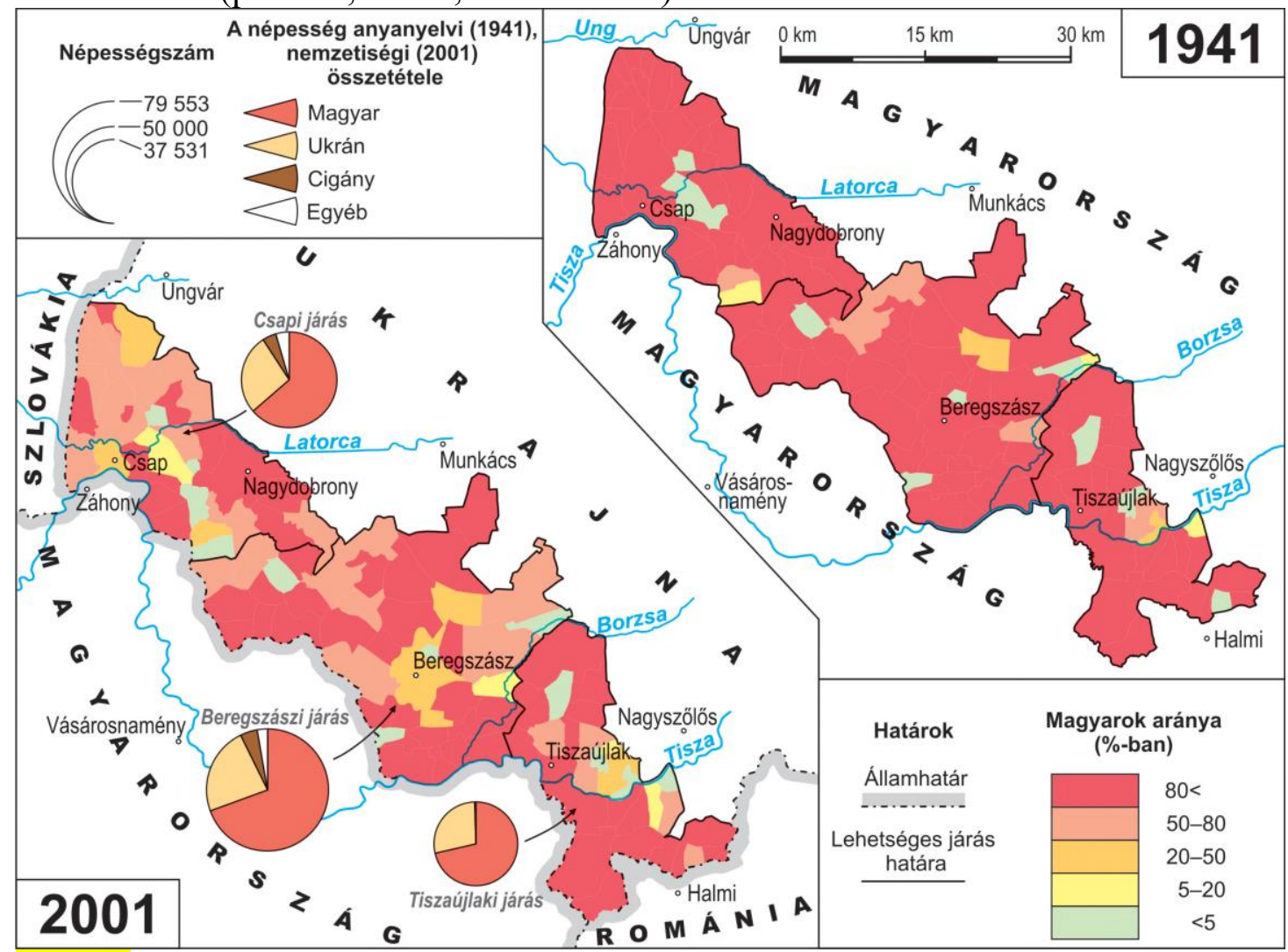

11.ábra Magyarok aránya a földrajzilag elképzelhetö, kárpátaljai „,Tiszamenti Autonóm Körzet” területén (1941, 2001)

\footnotetext{
${ }^{59}$ Ezen járások népességszáma meghaladná a ma is létező Nagybereznai, Perecsenyi, Volóci járásokét. Az így létrejövő határ menti járások a következők lennének: Csapi járás (48.907 lakos, 63,7\% magyar, 27,1\% ukrán); Beregszászi járás (79.553 lakos, 69,4\% magyar, 23,3\% ukrán); Tiszaújlaki járás (37.531 lakos, 71,4\% magyar, 28,1\% ukrán).
} 
2.táblázat A népesség anyanyelvi, nemzetiségi összetétele a földrajzilag elképzelhetö, kárpátaljai ,,Tiszamenti Autonóm Körzet” területén (1941-2001)

A romániai magyarság szinte teljes egésze az 1918-ig Magyarországhoz tartozó területeken, a tágabb értelemben vett Erdélyben él, ahol az elmúlt közel négy évtized alatt föként a felgyorsult elvándorlás miatt - lélekszámuk rohamosan csökkent (1977: 1,7 millió, 2002: 1,4 millió, 2011: 1,2 millió). Jelenleg az erdélyi magyarok közel fele a Székelyföldön, csaknem ötöde a Partium északnyugati részén él, míg harmada szórványban küzd a nemzetinyelvi fennmaradásáért. Az 1968-as közigazgatási reform óta a 16 erdélyi megye közül csupán Hargita és Kovászna magyar többségü. A jelenlegi 1192 erdélyi municipium, város és kommuna (,község”) közül 2011-ben 214 volt magyar anyanyelvi többségü. Az etnikai alapú területi önrendelkezés lehetősége a Kárpát-medencei kisebbségek lakta területek közül a demográfiai, gazdasági, történeti hátteret figyelembe véve az erdélyi Székelyföld esetében a legkézenfekvőbb. Az itt élő magyar (székely) lakosság a 14. századtól 1876-ig (illetve 19521960/68 között) rendelkezett ilyen területi önkormányzatisággal. A Székelyföldnek nevezett történeti-etnikai régió domináns magyar etnikai jellege a 13. századtól napjainkig változatlan. A helyi önkormányzati határokat érintetlenül hagyva, a vonzáskörzeti, etnikai viszonyokat és a történelmi hagyományokat figyelembe véve Hargita, Kovászna és Maros megyék magyar többségü városainak, kommunáinak társulásával elképzelhető egy olyan önkormányzati régió (,Székelyföldi Autonóm Régió”) létrejötte, mely 750 ezer (76,5\%-ban magyar, 21,5\%-ban román anyanyelvü) lakosnak nyújtana otthont (12.ábra, 3.táblázat). A városok, kommunák társulásával létrejövő terület az 1876-ig létezö székely székekhez (Székelyföldhöz) képest nem foglalná magában a román többségü Bodza- és Békás vidéket, Maroshévízt és környékét, de részét képezhetnék a szomszédos magyar többségü kommunák.

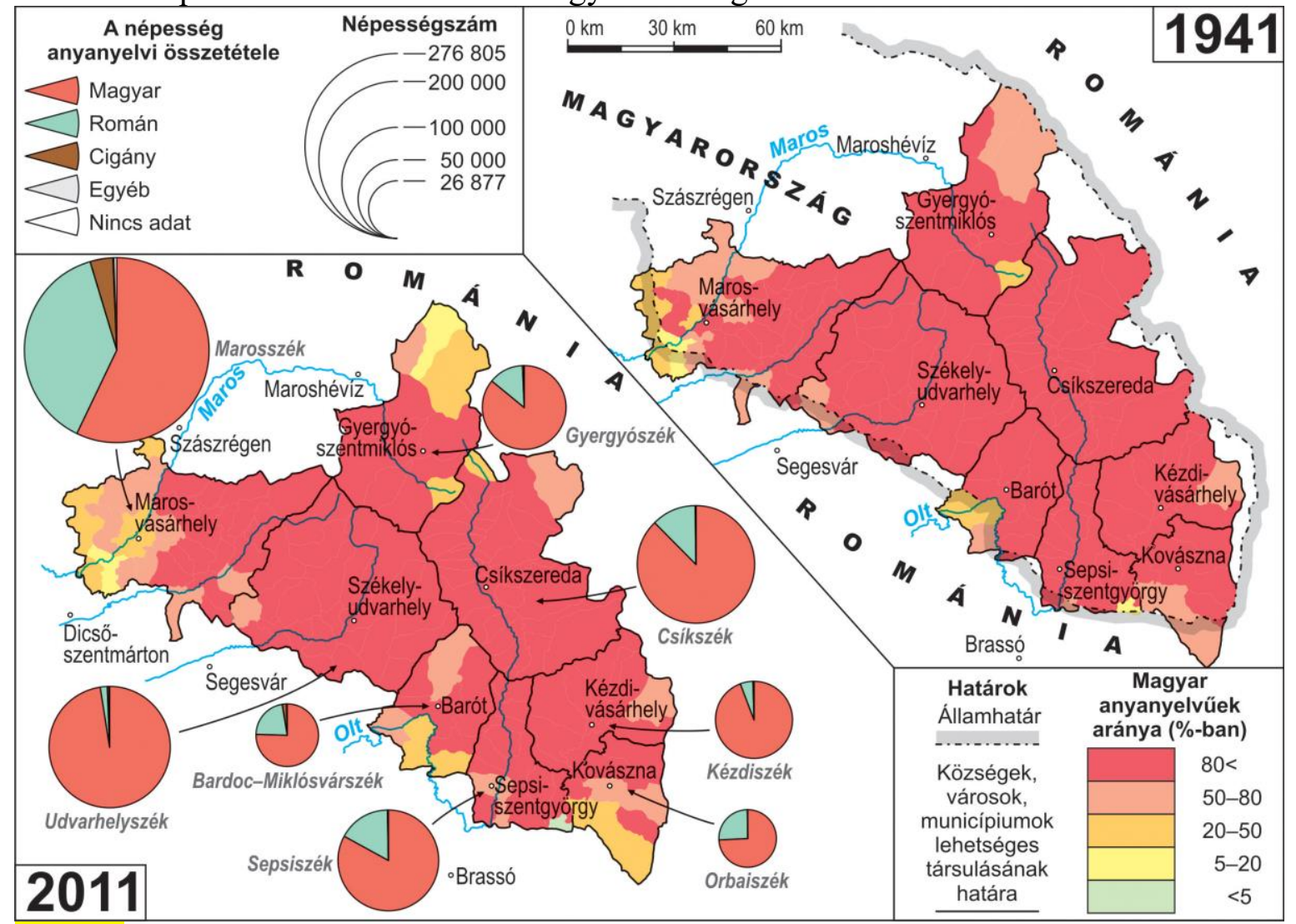

12.ábra Magyarok aránya a földrajzilag elképzelhető „Székelyföldi Autonóm Régió” területén $(1941,2001)$ 
3.táblázat A népesség anyanyelvi összetétele a földrajzilag elképzelhető „Székelyföldi Autonóm Régió” területén (1941-2011)

Románia és az ún. Partium (románul Crişana, Maramureş) északnyugati részén, Bihar, Szatmár és Szilágy megyék területén a vonzáskörzeti és etnikai szempontok alapján elképzelhető 86 (túlnyomórészt magyar többségü) város és kommuna társulása (, Partiumi Autonóm Körzet”), ahol 430 ezer (56\%-ban magyar, 41,1\%-ban román, 1,9\%-ban cigány anyanyelvü) lakos élvezhetné a területi alapú önrendelkezést (13.ábra, 4.táblázat). Ez a régió hozzávetőlegesen megegyezne azon képviselőházi választókörzetek együttes területével, ahol 2012. december 9-én is magyar párt nyerte el a választók többségének bizalmát. ${ }^{60} \mathrm{~A}$ nevezett székelyföldi és partiumi területeken kívül az erdélyi magyarok harmada maradna, föként a nagyvárosokban (pl. Kolozsvár 49 ezer, Nagyvárad 46 ezer, Brassó 16 ezer, Temesvár 15 ezer, Nagybánya 14 ezer) és az Erdélyi-medencében (pl. Kalotaszeg, Aranyosszék, Küküllövidék), ahol fơként a helyi és személyi elvü autonómia segíthetné etnikai önazonosságuk megőrzését.

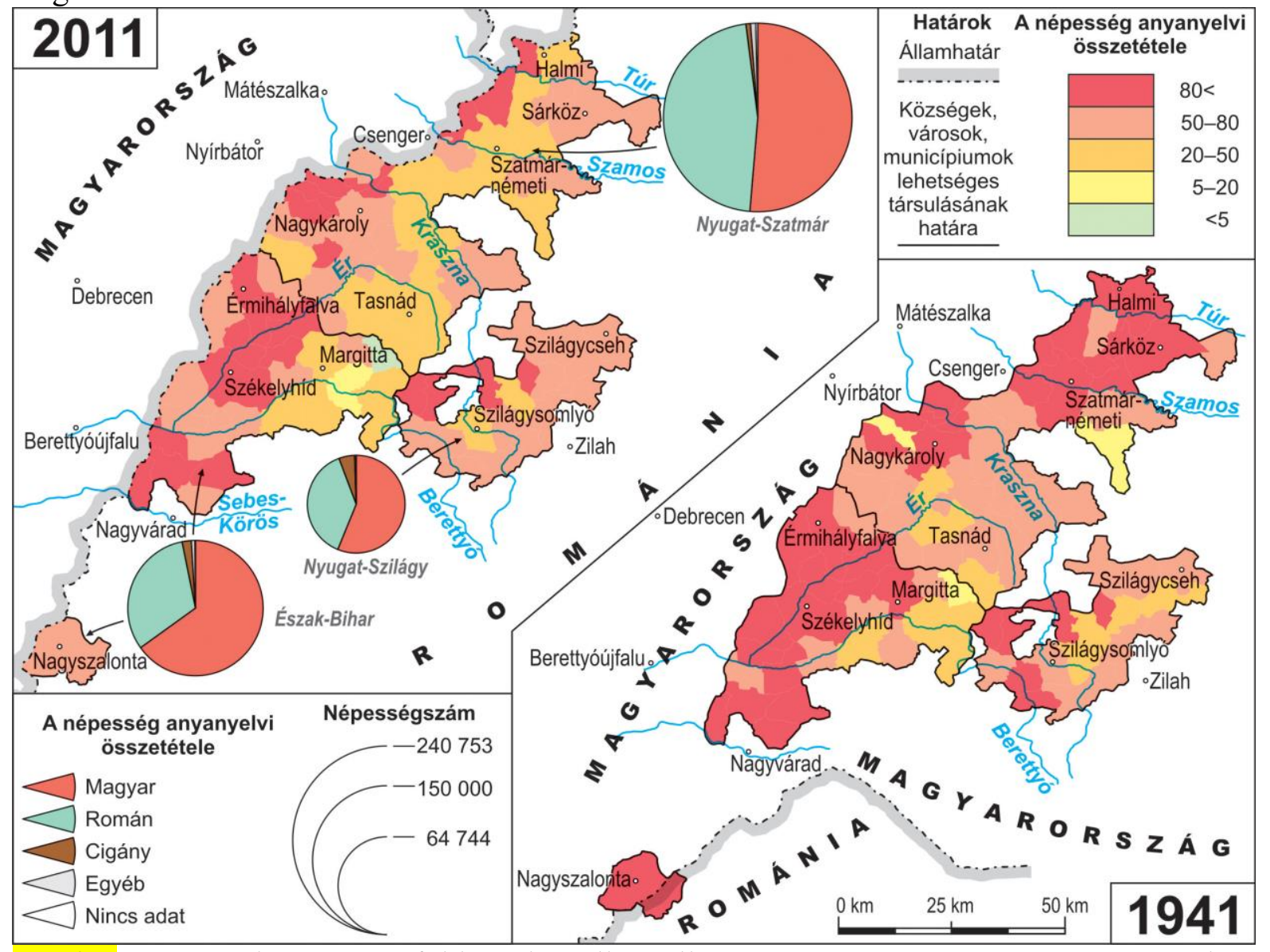

13.ábra Magyarok aránya a földrajzilag elképzelhetö „Partiumi Autonóm Körzet” területén (1941, 2001)

4.táblázat A népesség anyanyelvi összetétele a földrajzilag elképzelhetö „Partiumi Autonóm Körzet” területén (1941-2011)

${ }^{60}$ RMDSZ jelölt győzelmét eredményező képviselőházi választókörzetek Bihar megyében Székelyhíd (Săcueni), Margitta (Marghita), Szatmár megyében Nagykároly-Tasnád (Carei-Tăşnad), Sárköz (Livada), Szilágy megyében Szilágycseh (Cehu Silvaniei). 
A szerbiai magyarság szinte teljes egésze (251 ezer fó) a Vajdaság Autonóm Tartomány területén él, ahol 8 kommunában (kb. járás nagyságú „községben”) alkotja a helyi népesség többségét. Ezek a magyar-szerb határ és a Tisza közelében, Szabadka és Zenta vonzáskörzetében található közigazgatási egységek önkéntes társulásukkal létrehozhatnának egy „Észak-Bácskai Autonóm Körzetet”, melynek 301 ezer lakosa lehetne, akiknek 50,4\%-a lenne magyar, 25,8\%-a szerb és 9,5\%-a bunyevác, horvát (14.ábra, 5.táblázat). ${ }^{61}$ A vajdasági magyaroknak 40\%-a (100 ezer fö) jóllehet ezen a területen kívül rekedne, de etnikai identitásuk megőrzését a már megvalósult kulturális (személyi elvü) autonómiájuk, az országos kisebbségi önkormányzati szervük a Magyar Nemzeti Tanács már most is segíti.

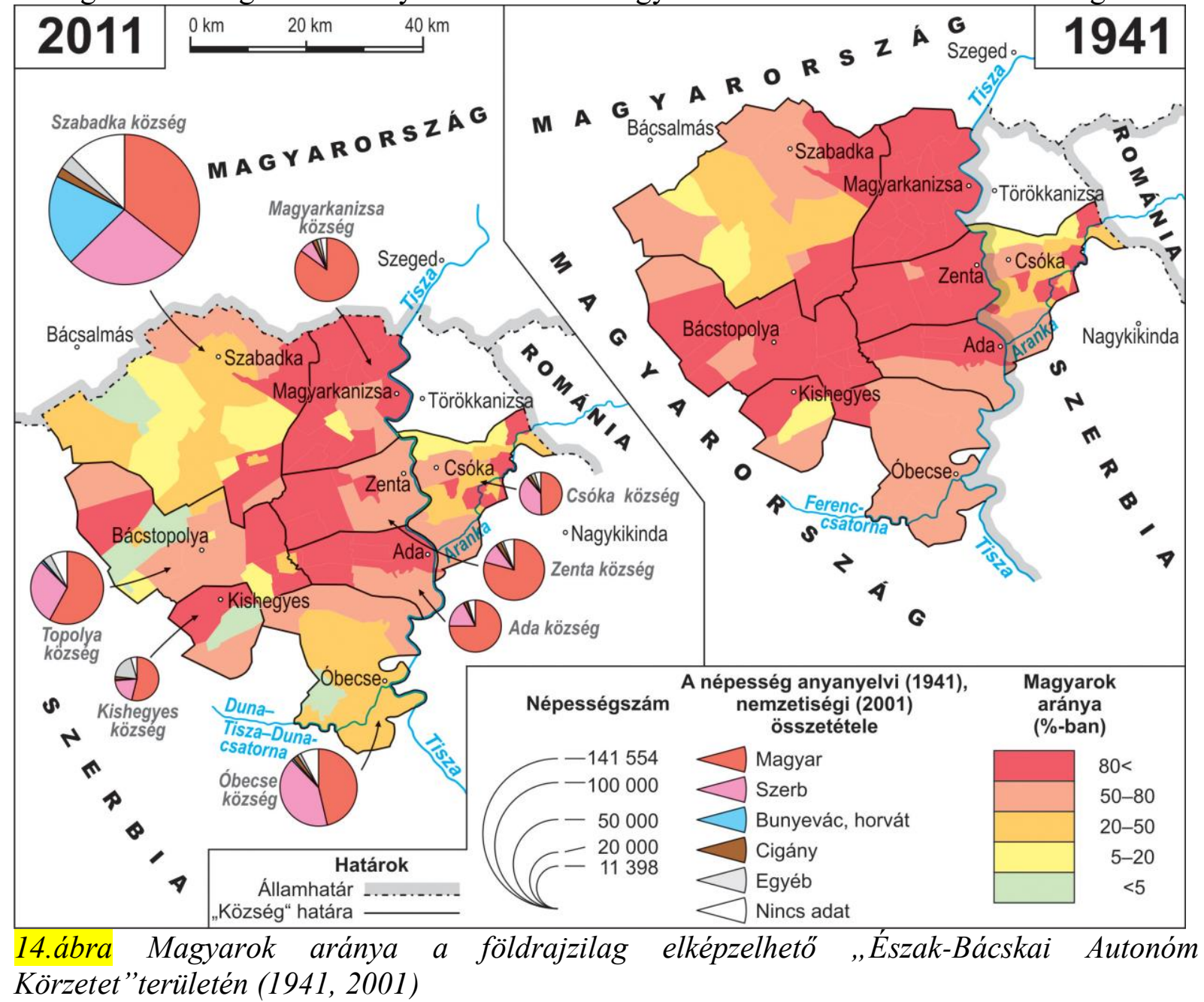

5.táblázat A népesség anyanyelvi, nemzetiségi összetétele a földrajzilag elképzelhetö „ÉszakBácskai Autonóm Körzetet” területén (1941-2001)

\section{Összegzés}

Az elmúlt évtizedekben világszerte, egymás után létrejövő (különösen az etnikai alapú) területi autonómiák, mint a kisebbségvédelem legfejlettebb eszközei és a kisebbségek belső önrendelkezésének legmodernebb formái nem számítanak újdonságnak a magyar állam történelmi területén, a Kárpát-medencében. Uralkodóink saját birtokaikon a 13. századtól adtak katonai szolgálatok fejében különböző etnikai csoportoknak (pl. szászok, székelyek,

${ }^{61}$ 1941-ben ezen a területen 327 ezer lakos élt, akiknek 74\%-a (242 ezer) volt magyar, 11,5\%-a (38 ezer) bunyevác, horvát és 10,1\%-a (33 ezer) szerb anyanyelvü. 
románok, kunok, jászok, szerbek) ilyen területi önkormányzatot, melyek többsége egészen a 19. század második feléig fennállt. A középkor végétől az ország etnikai arculatát alaposan átformáló népmozgalmi és háborús okok következtében a nemzeti kisebbségek aránya a 18. század végére, a modern nemzetek és a nacionalizmus kialakulásának kezdetére, a II. Józsefféle németesítő, felvilágosult abszolutizmus idejére megközelítette az ország népességének 2/3-át (a 15. század végén még csak minden harmadik lakos volt nem magyar). A kisebbségek demográfiai súlyuk, politikai öntudatuk, a magyar nacionalizmus által is kiváltott (de a Habsburg Birodalom által tüzelt) nacionalizmusuk fokozatos növekedésével a 19. század derekától egyre határozottabban követelték önálló politikai nemzeti mivoltuk és etnikai alapú területi autonómiájuk elismerését, megvalósítását.

A kiegyezést (1867) követően az Osztrák-Magyar Monarchiában gyakorlatilag belső önrendelkezést kapott magyar állam ugyanezt a jogot tagadta meg (a horvátoktól eltekintve) saját területén a nemzetiségektől. Az elutasítás oka ugyanaz volt, mint a mindmáig etnikailagpolitikailag egységes nemzetállamot építeni kívánó országok esetében is: rettegés a kisebbségek elszakadási törekvéseitől, az állam területi integritásának megbomlásától, az örökéletűnek remélt államhatárok megváltozásától. Sajnálatos, hogy a Szent István korától a 19. századig az etnikai-nyelvi tolerancia terén (az etnikai alapú területi autonómiák létrehozásával is) példamutató magyar állam a korszellemnek engedve, a francia államnemzeti eszme ábrándját követve a 19. század második felétől olyan hibát követett el a nemzetiségek (többek között) etnikai-területi önrendelkezési óhajának megtagadásával, mely a kisebbségek elidegenedését, az 1. világháború után kiválását, végeredményben az évezredes haza állami széthullását eredményezte.

1918 végén a soknemzetiségű Habsburg birodalom helyén soknemzetiségü, közepes méretü ,nemzetállamok” jöttek létre, melyek határait Magyarország rovására úgy húzták meg, hogy többnyire határvidékeiken több millió magyar került fennhatóságuk alá. Területi integritásuk védelme érdekében a szomszéd államok nem csupán a harmadrendűként kezelt magyar kisebbségek, hanem a másodrendünek tartott „társnemzeteik” (pl. szlovákok, ruszinok, horvátok) autonómia követeléseit is visszautasították, azok teljesítését a 2. világháború előtti pillanatokig halogatták.

Az 1938-1944 közötti időszakban a Harmadik Birodalom (hódító céljai érdekében) a Kárpát-medence térségében is kihasználta a két világháború között elnyomott nemzetek, kisebbségek elkeseredését, sikeresen alkalmazva a „divide et impera” ősi római elvet. A korábbi uralkodó nemzetek (csehek, románok, szerbek) országait az új határokkal visszaszorította etnikai törzsterületükre, a szlovákokat, horvátokat „függetlenséggel ajándékozta meg", a magyaroknak pedig engedélyezte a területi nemzetegyesítést, az 1919ben elveszített magyarlakta területek visszacsatolását.

A 2. világháború után a Szovjetunió befolyása (többnyire katonai ellenőrzése) alá került Kárpát-medence országaiban (Ausztriát kivéve) szovjet típusú kommunista államigazgatási rendszerek épültek ki, melyek a későbbi évtizedekben is (az egyébként is kisebbségellenes közhangulatban) lehetetlenné tették az etnikai alapú, tényleges területi önrendelkezés megvalósítását. Efelé mutattak az 1944-1950 közötti kényszermigrációk is, melyek a németek szinte teljes egészének eltávolításával, a magyar kisebbségek meggyengítésével, hatalmas méretü szlovák, ukrán, orosz, román, szerb kolonizációval jelentős mértékben átformálták a régió etnikai térszerkezetét. A szocialista évtizedekben területi autonómiaként csak a jugoszláviai Vajdaság tartós (1945-1989) és a romániai Magyar Autonóm Tartomány ideiglenes (kikényszerített, 1952-1960/68 közötti) léte említhető csak meg.

A délszláv háborúk idején felvillant a horvátországi szerb Krajina területi autonómiája, majd függetlenedése is, hogy 1995-ben végérvényesen a történelmi múlt része legyen. A rendszerváltozást követő években a Kárpát-medence jelentős magyar kisebbségei kidolgozták 
többnyire háromlépcsős autonómia koncepcióikat. Azok keretében azonnal megfogalmazták, gyakran törvénytervezetekként be is nyújtották területi önrendelkezésre vonatkozó elképzeléseiket is, melyeket a szlovák, ukrán, román, szerb fél azonnal (esetenként többször) vissza is utasított.

A társadalmi-gazdasági rendszerváltozás (1990- ), a világgazdasági válság (2008- ) okozta sokkhatás, a jólét hiánya, fokozódó társadalmi polarizáció, a korábbi erős központi hatalom megszünése, a demokratikus civil társadalom hagyományának hiánya, nagyszámú etnikai- és nemzeti kisebbség léte és bizonyos keserü történelmi tapasztalatok miatt a politika a Kárpát-medence országaiban is gyakran nyúl a nacionalizmus fegyveréhez. A nacionalista erők gyakran provokálják a kisebbségeket, különösen, ha azok nagy létszámúak és viszonylag kompakt etnikai területen élnek, hogy bizonyítsák a kisebbségek léte jelentette (gyakran irredenta) veszélyt. Az itteni kormányok a gazdasági-politikai nehézségek következtében inkább az állami funkciók központosítására törekednek, mint a regionális hatalommegosztásra, föként nem az etnikai alapú területi autonómiák megvalósítására, melyet az államalkotó nemzetek az állam területi integritása elleni nyílt támadásként értékelnek. $\mathrm{E}$ tekintetben a sikeres, pozitív európai példák helyett a sikertelenek (pl. Koszovó, Abházia, Dél-Oszétia, Karabah, Krím) tanulságait hangsúlyozzák.

A Kárpát-medencében az etnikai alapú területi önrendelkezés földrajzi, demográfiai feltételei a szlovákiai, kárpátaljai, erdélyi (székelyföldi és partiumi), illetve vajdasági magyar nemzeti közösségek lakóhelyeinek többsége esetében adottak. A politikai feltételek a fentiekben vázolt okok miatt rövid- és középtávon, gyakran még a helyi önkormányzatok társulásának megvalósítási kísérlete esetében is úgy tủnik, hogy egyelöre még hiányoznak.

\section{Irodalom}

Ackrén, Maria 2009. Conditions for Different Autonomy Regimes in the World, Åbo Akademi University Press, Åbo.

Bakk Miklós 2012. Az autonómia kronológiája. Erdélyi Napló XXII. 43. (2012. október 25.) pp.8-9.

Bakker, Edwin 1997. Minority conflicts in Slovakia and Hungary? Labyrint Publication, Capelle a/d IJssel.

Baletić, Z. et al. 1994. Kroatien zwischen Aggression und Frieden, AGM, Zagreb.

Bánkiné Molnár Erzsébet 2005. A jászkun autonómia. Dél-Alföldi Évszázadok 22. Szeged.

Bárdi Nándor-Éger György 2000. Útkeresés és integráció. Határon túli magyar érdekvédelmi szervezetek dokumentumai 1989-2000. TLA, Budapest.

Bárdi Nándor 2004. Javaslatok, modellek az erdélyi kérdés kezelésére (A magyar elképzelések, 1918-1940). Magyar Kisebbség 9. 1-2. pp.329-376.

Bárdi Nándor 2008. A romániai magyar kisebbség helyzetének változásai, társadalmi, kulturális önszerveződésének eredményei. In: Bárdi Nándor - Fedinec Csilla - Szarka László (szerk.) 2008. Kisebbségi magyar közösségek a 20. században. Gondolat Kiadó - MTA Kisebbségkutató Intézet, Budapest, pp. 330-339.

Benedikter, Thomas 2009. The World's Modern Autonomy Systems. Concepts and Experiences of Regional Territorial Autonomy. Institute of Minority Rights EURAC Research, Bolzano.

Beréti László 2010. Autonomy is being taken. Hadtudományi Szemle 3. 4. pp. 46-49.

Bereznay András 2011. Erdély történetének atlasza, Méry Ratio, Budapest.

Bibó István 1986. A kelet-európai kis államok nyomorúsága. Válogatott tanulmányok. II. kötet, Magvető, Budapest. 
Bognár Z. (szerk.) Romániai autonómia-elképzelések 1989 után: www.adatbank.ro/belso.php?alk=48\&k=5

Botlik József-Dupka György 1993. Magyarlakta települések ezredéve Kárpátalján. Intermix, Ungvár-Budapest.

Botlik József 2005. Közigazgatás és nemzetiségpolitika Kárpátalján I-II. Nyíregyháza.

Bottoni, Stefano 2008. Sztálin a székelyeknél. A Magyar Autonóm Tartomány története, 1952-1960. Pro-Print, Csíkszereda.

Csapó I. József 2003. 2.2. Memorandum Tervezet A Romániai Magyar Nemzeti Közösség Belső Önrendelkezéséről (1992). In: Csapó I. József. Autonómiák és autonómiatörekvések, H.n. pp. 262-274.

Csáky Pál 1996. A szlovákiai magyarság autonómiatörekvései. Pro Minoritate 5. 1. pp.4-8.

Csuka János 1995. A délvidéki magyarság története 1918-1941. Püski, Budapest.

Csutak István 2007. Új? Régi? Jó? Alutus, Csíkszereda.

Czibulka Z.-Heinz E.-Lakatos M. 2004 A magyarországi németek kitelepítése és az 1941. évi népszámlálás. Központi Statisztikai Hivatal. Budapest

Czoernig, Karl 1857. Ethnographie der Oesterreichischen Monarchie. II. Band. Wien.

Dakić, M. 1994. The Serbian Krayina. Historical Roots and Its Birth. Iskra, Knin.

Đorđević, Jovan 1861. Karta Bačke, Srema i Banata sa predloženima od blagoveštenskoga sabora za Vojvodinu Srbsku. N. Fux, Novi Sad.

Duray Miklós-Kvarda József-Oriskó Norbert 1994. A nemzetállam és demokratikus ellenszere. Együttélés-Spolužitie, Pozsony/Bratislava.

Edvi I. Aladár - Halász Albert 1920. La Hongrie économique en cartes - The Economies of Hungary in Maps - Magyarország gazdasági térképekben. Budapest.

Egyed Ákos 2006. A székelyek rövid története a megtelepedéstől 1918-ig. Pallas-Akadémia Kiadó, Csíkszereda.

Elekes Tibor 2011. Székelyföld közigazgatás-földrajzi változásai a 13. századtól napjainkig. Földrajzi Közlemények 135. 4. pp.415-429.

Endes Miklós 1935. Erdély három nemzete és négy vallása autonómiájának története, Budapest.

Érszegi Géza 2004. The Andreanum. The first known legal framework of regional selfadministration, SENCE J.v.Komlossy, Budapest.

Fazekas Márta 2009. Délvidéki és felvidéki autonómia a XX. század utolsó évtizedében. Lehetőség vagy ábránd? In: Kupa László (szerk.) Kisebbségi autonómia-törekvések Közép-Európában - a múltban és a jelenben, PTE - Bookmaster Kft., Pécs, pp.163169.

Fedinec Csilla 2001. Kárpátaljai autonómia-koncepciók 1918-1944 között. Kisebbségkutatás 11.3.pp.450-469.

Fedinec Csilla 2002. A kárpátaljai magyarság történeti kronológiája 1918-1944. Fórum Intézet - Lilium Aurum, Galánta - Dunaszerdahely.

Fedinec Csilla 2008. A kárpátaljai magyar kisebbség helyzetének változásai Ukrajnában. In: Bárdi Nándor - Fedinec Csilla - Szarka László (szerk.) 2008. Kisebbségi magyar közösségek a 20. században. Gondolat Kiadó - MTA Kisebbségkutató Intézet, Budapest, pp.346-353.

Fekete Nagy Antal 1934. A Szepesség területi és társadalmi kialakulása, Budapest.

Fekete Nagy Antal - Makkai László (szerk.) 1941. Documenta historiam Valachorum in Hungaria illustrantia usque ad annum 1400 p. Christum. L'études sur L'Europe Centre-Orieantale 29, Budapest.

Fodor Ferenc 1942. A Jászság életrajza, Szent István Társulat, Budapest.

Fogarasi Zoltán 1944. A népesség anyanyelvi, nemzetiségi és vallási megoszlása törvényhatóságonkint 1941-ben. Statisztikai Szemle 1-3. 1-20. 
Gábrity Molnár Irén 2009. Kisebbségi autonómia-törekvések a Vajdaságban. In: Kupa László (szerk.) Kisebbségi autonómia-törekvések Közép-Európában - a múltban és a jelenben, PTE - Bookmaster Kft., Pécs, pp.117-129.

Gerencsér Balázs - Juhász Albin 2001. A kisebbségi autonómia (müködő modellek, magyar elképzelések). Budapest.

Ghai, Yash (ed.) 2002. Autonomy and Ethnicity: Negotiating Competing Claims in MultiEthnic States. Cambridge University Press, Cambridge.

Gyárfás István 1870-1885. A jász-kunok története I-IV., Kecskemét - Szolnok - Budapest.

Gyönyör József 1994. Terhes örökség. A magyarság lélekszámának és sorsának alakulása Csehszlovákiában. Madách-Posonium, Pozsony/Bratislava.

Györffy György 1939. Besenyők és magyarok. Körösi Csoma Archívum, Budapest.

Halás, Marián-Klapka, Pavel 2012. Contribution to regional division of Slovakia based on the application of Reilly's model. Hungarian Geographical Bulletin 61. 3. pp. 237-255.

Hamberger Judit 2008. A magyar kisebbség jogi-politikai helyzete Szlovákiában 1989 novembere után. In: Bárdi Nándor - Fedinec Csilla - Szarka László (szerk.) 2008. Kisebbségi magyar közösségek a 20. században. Gondolat Kiadó - MTA Kisebbségkutató Intézet, Budapest, pp. 340-345.

Hanzó Lajos 1941. Az erdélyi szász önkormányzat kialakulása. Értekezések a M. Kir. Horthy Miklós Tudományegyetem Magyar Történelmi Intézetéből, Szeged.

Hegediš, Antal - Čobanović, Katarina 1991. Demografska i agrarna statistika Vojvodine 1767-1867. Filozofski Fakultet u Novom Sadu, Institut za istoriju, Novi Sad.

Jordan, Peter 2010. Verwaltungsgliederung Mittel- und Südosteuropas 2007. Atlas Ost- und Südosteuropa 5.4-G.10. ISR ÖAW, Wien.

Katus László 1993. Egy kisebbségi törvény születése. Az 1968. évi nemzetiségi törvény évfordulójára. Regio. 4. 4. 99-128.

Katus László 2002. Nemzetiségi kérdés, nemzetiségi politika 1848-1849-ben. Kisebbségkutatás 11. 1. 66-76.

Kemény G. Gábor 1952. Iratok a nemzetiségi kérdés történetéhez Magyarországon a dualizmus korában (1867-1918). Tankönyvkiadó, Budapest.

Klemenčić, Mladen 1992. Trojednica s BiH. Državnost i granice (2). Novi Vjesnik CIII. 16053. 1992.06.01.

Kocsis Károly 1992. Changing ethnic, religious and political patterns in the Carpatho-Balkan area. In: Kertész Á.-Kovács Z. (eds.) New perspectives in Hungarian geography. Studies in Geography in Hungary 27. Akadémiai Kiadó, Budapest, pp.115-142.

Kocsis Károly 1993. Jugoszlávia. Egy felrobbant etnikai mozaik esete. Az etnikai konfliktusok történeti-földrajzi háttere a volt Jugoszlávia területén. Teleki László Alapítványa, Budapest.

Kocsis Károly 1999. Die ethnische Struktur in den Grenzräumen der karpatho-pannonischen Region. In: Schultz H (Hrsg.) Bevölkerungstransfer und Systemwandel. Ostmitteleuropäische Grenzen nach dem Zweiten Weltkrieg. Verlag Arno Spitz GmbH, Berlin. pp. 69-104.

Kocsis Károly 2002. A közigazgatási térfelosztás változásai a mai Szlovákia területén a XX. században. In: Pásztor Cecília (szerk.) „Ahol a határ elválaszt” Trianon és következményei a Kárpát-medencében. Nógrád Megyei Levéltár, Balassagyarmat, pp.131-153.

Korhecz Tamás 2009. Otthonteremtőben a szülőföldön. Fórum, Újvidék/Novi Sad.

Korhecz Tamás 2010. Magyar autonómia Szerbiában. A programcéltól a hatályos törvényig. Pro Minoritate 2010.tavasz. 67-73.

Kovács Péter 1996. Egyéni és kollektív kisebbségi jogok az alkotmányos fejlődésben pozitivista szempontból. Magyar Kisebbség 2. 3. pp. 17-38. 
Kristó Gyula 2003. Nem magyar népek a középkori Magyarországon, Lucidus, Budapest.

Lőkkös János 2000. Trianon számokban. Püski, Budapest.

Macartney, C. A. 1937. Hungary and her successors. The Treaty of Trianon and its consequences 1919-1937. Oxford University Press, London-New York-Toronto.

Makkai László 1948. Magyar-román közös múlt, Budapest.

Mester Miklós 1936. Az autonóm Erdély és a román nemzeti követelések az 1863-64. évi nagyszebeni országgyülésen. Budapest.

Michniak, Daniel 2006. Zázemia vybraných centier dochádzky do zamestnania v roku 2001. In: Atlas obyvatel'stva Slovenska, Univerzita Komenského, Bratislava.

Molnár Gusztáv 1992. Önrendelkezési törekvések az „Észak-Erdélyi Köztársaság” idején. In: Molnár Gusztáv (szerk.) Autonómia és integráció. Magyar Szemle - Magyarországért Alapítvány, Budapest, pp.92-139.

Molnár Jenő 1992. Területi-közigazgatási felosztás Erdélyben (1876-1968). Korunk 3. 9. pp. 88-97.

Molnár Margit 2009. Felvidéki magyar autonómia-törekvések. In: Kupa László (szerk.) Kisebbségi autonómia-törekvések Közép-Európában - a múltban és a jelenben, PTE Bookmaster Kft., Pécs, pp.170-180.

Müller, Georg Eduard 1928. Die sächsische Nationsuniversität. Verein für Siebenbürgische Landeskunde, Hermannstadt.

Oficicinszkij, Román 2010. Kárpátontúli Ukrajna, 1944-1946. In: Fedinec Csilla-Vehes, Mikola (föszerk.) Kárpátalja 1919-2009 történelem, politika, kultúra. Argumentum, MTA Etnikai-nemzeti Kisebbségkutató Intézete, Budapest. pp.233-245.

Oriskó Norbert 1993. Magyarok által lakott községek és városok Szlovákiában. Együttélés, Pozsony/Bratislava.

Osztapec Jurij 2010. Politikai folyamatok Kárpátalján (1991-2009). In: Fedinec Csilla-Vehes, Mikola (föszerk.) Kárpátalja 1919-2009 történelem, politika, kultúra. Argumentum, MTA Etnikai-nemzeti Kisebbségkutató Intézete, Budapest. pp. 377-392.

Az önkormányzat az önrendelkezés alapja. A szlovákiai magyar választott képviselök és polgármesterek országos nagygyülésének hiteles jegyzőkönyve. Komárom, 1994. január 8. Komáromi Lapok - Szinnyei Kiadó, Komárom.

Pálóczi Horváth András 1989. Besenyők, kunok, jászok, Hereditas, Budapest.

Pan, Christoph - Pfeil, Beate S. 2003. National Minorities in Europe: Handbook, Vol. 1, Braumüller ETHNOS, Vienna.

Pop, Ivan 2005. Dějiny Podkarpatské Rusi v datech. Nakladelstvi Libri, Praha.

Ríz Ádám 2000. Az 1990 után született autonómiakoncepciók összehasonlítása (I). Korunk 3. folyam, XI. 2. pp.81-86.

Rónai András 1937. A nemzetiségi kérdés területi megoldásai. Magyar Szemle 31.3. pp.201209.

Rónai András 1989. Térképezett történelem. Magvető, Budapest.

Salat Levente 2004. Autonómiák évadja Erdélyben. Krónika VI. 6. 2004. január 10-11.

Schneider Árpád 1941. A visszafoglalt délvidéki terület. Népességi és gazdasági áttekintés. Statisztikai Szemle 11. pp. 767-786.

Silber, Laura - Little, Allan 1995. The death of Yugoslavia. Penguin Books - BBC Books, London.

Stark Tamás 1989. Magyarország második világháborús embervesztesége. MTA Történettudományi Intézet, Budapest.

Strugar, Vlado 1976. Jugoslavija: federacija i republika. Narodna knjiga, Beograd.

Surányi Zoltán 2001. „Mindannyian akarjuk, de...” Autonómiaviták a Vajdaságban. Beszélő. 2001. 6. 9. (szeptember) http://beszelo.c3.hu/cikkek/\%E2\%80\%9Emindannyianakarjuk-de\%E2\%80\%9D 
Szabó Pál Zoltán 1945. Horvátország és mai részei a magyar történelemben. Földrajzi Zsebkönyv, Magyar Földrajzi Társaság, Budapest, pp. 210-233.

Szádeczky Kardoss Lajos 1927. A székely nemzet története és alkotmánya. Budapest.

Szarka László 1990. A méltányos nemzeti elhatárolódás lehetősége 1918 végén. Regio 1.1. pp. 49-65.

Szarka László 2008. A történeti Magyarország felbomlása: katonai akciók, demarkációs vonalak. In: Bárdi Nándor - Fedinec Csilla - Szarka László (szerk.) 2008. Kisebbségi magyar közösségek a 20. században. Gondolat Kiadó - MTA Kisebbségkutató Intézet, Budapest, pp. 14-21.

Szarka László 2008. Útkeresés, önszerveződés a rendszerváltás éveiben (1989-1991). In: Bárdi Nándor - Fedinec Csilla - Szarka László (szerk.) 2008. Kisebbségi magyar közösségek a 20. században. Gondolat Kiadó - MTA Kisebbségkutató Intézet, Budapest, pp. 320-329.

Szász Zoltán 1988. Kormánypolitika és nemzetiségek. In: Glatz Ferenc (szerk.) Magyarok a Kárpát-medencében, Pallas, Budapest, pp.175-180.

Szentgyörgyi Mária 1972. Kővár-vidék társadalma. Értekezések a történettudomány köréből 56. Budapest.

Szilágyi Ferenc 2010. Az új román területi közigazgatás lehetséges elvi alapjai. Magyar Kisebbség Új sorozat XV. 3-4. (57-58) pp. 225-246.

Szilágyi Ferenc-Csomortányi István 2010. Önrendelkezés a Partiumban. Partium Kiadó, Nagyvárad.

Szvatkó Pál 1937. Svájci példa. A három magyar kanton Új Szellem. 9. pp.20-21.

Thirring Lajos 1939. A visszatért kárpátaljai területen végrehajtott népösszeírás előzetes eredményei. Statisztikai Szemle 8. pp. 939-950.

Thirring Lajos 1940. A visszacsatolt keleti terület. Terület és népesség. Statisztikai Szemle 89. pp. 662-679.

Thirring Lajos 1942. Vármegyéink területe, népességfejlődése, népsűrüsége és közigazgatási felosztása. Statisztikai Szemle 4. pp. 177-183.

Tilkovszky Lóránt 2000. Területi integritás és területi autonómia. A magyar kormány 1920. évi felvidéki szlovák autonómia-terve. Századok, 134 (2000), 3. sz. pp.555-596.

Tóth István 1993. Autonómia: Kárpátaljai vágyak és a valóság. In: Molnár Gusztáv (szerk.) Autonómia és integráció. Magyar Szemle - Magyarországért Alapítvány, Budapest, pp.64-91.

Varga E. Árpád 1992. Népszámlálások a jelenkori Erdély területén. Regio - MTA Történettudományi Intézet, Budapest, 1992.

Vincze Gábor 1994. A romániai magyar kisebbség történeti kronológiája 1944-1953. TLAJATE, Budapest-Szeged.

Weilguni, Werner - Suppan, Arnold - Heuberger, Valeria - Koch, Klaus 1991. Die Wahlen des Jahres 1990 in Mittel-, Ost- und Südosteuropa. Atlas Ost- und Südosteuropa 6.1G.3, ÖOSI, Wien.

Zahorán Csaba 2009. Egy kis Magyarország Nagy-Romániában. Alternatívák a Székelyföldre a két világháború közötti magyar tervezetekben. Magyar Kisebbség 2009.1-2. pp.133149.

Žudel, Juraj 1984. Stolice na Slovensku, OBZOR, Bratislava.

\section{TÁBLÁZATOK}

1.táblázat A népesség anyanyelvi összetétele a földrajzilag elképzelhető „Dél-Szlovákiai Autonóm Régió" területén (1941-2011) 


\begin{tabular}{|c|r|r|r|r|r|r|r|r|r|}
\hline \multirow{2}{*}{ év } & $\begin{array}{l}\text { Össz- } \\
\text { népesség }\end{array}$ & magyarok & szlovákok & cigányok & egyebek & magyarok & szlovákok & cigányok & egyebek \\
\cline { 2 - 9 } & \multicolumn{9}{|c|}{ száma } \\
\hline 1941 & 571.198 & 545.481 & 18.854 & 3.433 & 3.430 & 95,5 & 3,3 & 0,6 & 0,6 \\
\hline 2001 & 681.148 & 473.912 & 184.556 & 10.142 & 12.538 & 69,6 & 27,1 & 1,5 & 1,8 \\
\hline 2011 & 680.493 & 432.445 & 189.719 & 11.196 & 47.133 & 63,5 & 27,9 & 1,6 & 7,0 \\
\hline
\end{tabular}

Forrás: A magyar (1941) és szlovák (2001, 2011) népszámlálások anyanyelvi adatai.

2.táblázat A népesség anyanyelvi, nemzetiségi összetétele a földrajzilag elképzelhetö, kárpátaljai „,Tiszamenti Autonóm Körzet” területén (1941-2001)

\begin{tabular}{|c|c|c|c|c|c|c|c|c|c|c|c|}
\hline év & $\begin{array}{l}\text { össz- } \\
\text { népesség }\end{array}$ & magyarok & ukránok & oroszok & cigányok & egyebek & magyarok & ukránok & oroszok & cigányok & egyebe \\
\hline & \multicolumn{6}{|c|}{ száma } & \multicolumn{5}{|c|}{ aránya (\%-ban) } \\
\hline 1941 & 758 & 113.466 & 8.375 & & 47 & 1.870 & 91,7 & 6,8 & & 0,0 & 1 \\
\hline 1989 & 275 & 115.211 & 42.884 & 4.648 & 4.900 & 1.632 & 68,1 & 25,3 & 2,7 & 2,9 & \\
\hline 2001 & 165.991 & 113.175 & 42.377 & 2.850 & 6.497 & 3.657 & 68,2 & 25,5 & 1,7 & 3,9 & \\
\hline
\end{tabular}

Forrás: A magyar (1941), szovjet (1989) és ukrán (2001) népszámlálások anyanyelvi (1941) és nemzetiségi $(1989,2001)$ adatai.

3.táblázat A népesség anyanyelvi összetétele a földrajzilag elképzelhető „Székelyföldi Autonóm Régió" területén (1941-2011)

\begin{tabular}{|r|r|r|r|r|r|r|r|r|r|}
\hline \multirow{2}{*}{ év } & $\begin{array}{l}\text { össz- } \\
\text { népesség }\end{array}$ & magyarok & románok & cigányok & egyebek & magyarok & románok & cigányok & egyebek \\
\cline { 2 - 9 } & \multicolumn{9}{|c|}{ száma } \\
\hline 1941 & 615.945 & 558.911 & 43.592 & 8 & 13.434 & 90,7 & 7,1 & 0,0 & 2,2 \\
\hline 2002 & 806.153 & 618.753 & 173.865 & 12.367 & 1.168 & 76,8 & 21,6 & 1,5 & 0,1 \\
\hline 2011 & 750.117 & 573.724 & 161.357 & 12.571 & 2.465 & 76,5 & 21,5 & 1,7 & 0,3 \\
\hline
\end{tabular}

Forrás: A magyar (1941) és román $(2002,2011)$ népszámlálások anyanyelvi adatai.

4.táblázat A népesség anyanyelvi összetétele a földrajzilag elképzelhető „Partiumi Autonóm Körzet” területén (1941-2011)

\begin{tabular}{|c|r|r|r|r|r|r|r|r|r|}
\hline \multirow{2}{*}{ év } & $\begin{array}{l}\text { össz- } \\
\text { népesség }\end{array}$ & magyarok & románok & cigányok & egyebek & magyarok & románok & cigányok & egyebek \\
\cline { 2 - 10 } & \multicolumn{9}{|c|}{ száma } \\
\hline 1941 & 430.790 & 324.945 & 92.839 & 2.275 & 10.731 & 75,4 & 21,6 & 0,5 & 2,5 \\
\hline 2002 & 470.046 & 257.758 & 196.508 & 8.656 & 7.124 & 54,9 & 41,8 & 1,8 & 1,5 \\
\hline 2011 & 429.528 & 240.671 & 176.336 & 8.012 & 4.509 & 56,0 & 41,1 & 1,9 & 1,0 \\
\hline
\end{tabular}

Forrás: A magyar (1941) és román $(2002,2011)$ népszámlálások anyanyelvi adatai.

5.táblázat A népesség anyanyelvi, nemzetiségi összetétele a földrajzilag elképzelhetö „ÉszakBácskai Autonóm Körzetet" területén (1941-2001)

\begin{tabular}{|r|r|r|r|r|r|r|r|r|r|}
\hline \multirow{2}{*}{ év } & $\begin{array}{l}\text { össz- } \\
\text { népesség }\end{array}$ & magyarok & szerbek & $\begin{array}{l}\text { bunyevácok, } \\
\text { horvátok }\end{array}$ & egyebek & magyarok & szerbek & $\begin{array}{l}\text { bunyevácok, } \\
\text { horvátok }\end{array}$ & egyebek \\
\cline { 2 - 9 } & \multicolumn{9}{|c|}{ száma } \\
\hline 1941 & 327.028 & 241.998 & 32.908 & 37.658 & 14.464 & 74,0 & 10,1 & 11,5 & 4,4 \\
\hline 2002 & 327.031 & 173.279 & 79.774 & 34.540 & 70.524 & 53,0 & 24,4 & 10,6 & 12,0 \\
\hline 2011 & 301.305 & 151.999 & 77.679 & 28.678 & 42.949 & 50,4 & 25,8 & 9,5 & 14,3 \\
\hline
\end{tabular}

Forrás: A magyar (1941) és szerb $(2002,2011)$ népszámlálások anyanyelvi (1941) és nemzetiségi $(2002,2011)$ adatai. 